Article

\title{
Exploring the Anti-Cancer Mechanism of Novel 3,4'-Substituted Diaryl Guanidinium Derivatives
}

\author{
Viola Previtali ${ }^{1}{ }^{\circledR}$, Helene B. Mihigo ${ }^{1}$, Rebecca Amet ${ }^{2}$, Anthony M. McElligott ${ }^{3}{ }^{\circledR}$, \\ Daniela M. Zisterer ${ }^{2}$ and Isabel Rozas ${ }^{1, *(\mathbb{D})}$ \\ 1 School of Chemistry, Trinity Biomedical Sciences Institute (TBSI), Trinity College Dublin (TCD), \\ 152-160 Pearse Street, D02R590 Dublin 2, Ireland; Viola.Previtali@iit.it (V.P.); mihigoh@tcd.ie (H.B.M.) \\ 2 School of Biochemistry and Immunology, Trinity Biomedical Sciences Institute (TBSI), Trinity College \\ Dublin (TCD), 152-160 Pearse Street, D02R590 Dublin 2, Ireland; ametr@tcd.ie (R.A.); dzistrer@tcd.ie (D.M.Z.) \\ 3 Trinity Translational Medicine Institute, Trinity College and St James's Hospital, D02R590 Dublin 8, Ireland; \\ Tony.McElligott@tcd.ie \\ * Correspondence: rozasi@tcd.ie
}

Received: 16 November 2020; Accepted: 16 December 2020; Published: 21 December 2020

check for updates

\begin{abstract}
We previously identified a guanidinium-based lead compound that inhibited BRAF through a hypothetic type-III allosteric mechanism. Considering the pharmacophore identified in this lead compound (i.e., "lipophilic group", "di-substituted guanidine", "phenylguanidine polar end"), several modifications were investigated to improve its cytotoxicity in different cancer cell lines. Thus, several lipophilic groups were explored, the di-substituted guanidine was replaced by a secondary amine and the phenyl ring in the polar end was substituted by a pyridine. In a structure-based design approach, four representative derivatives were docked into an in-house model of an active triphosphate-containing BRAF protein, and the interactions established were analysed. Based on these computational studies, a variety of derivatives was synthesized, and their predicted drug-like properties calculated. Next, the effect on cell viability of these compounds was assessed in cell line models of promyelocytic leukaemia and breast, cervical and colorectal carcinomas. The potential of a selection of these compounds as apoptotic agents was assessed by screening in the promyelocytic leukaemia cell line HL-60. The toxicity against non-tumorigenic epithelial MCF10A cells was also investigated. These studies allowed for several structure-activity relationships to be derived. Investigations on the mechanism of action of representative compounds suggest a divergent effect on inhibition of the MAPK/ERK signalling pathway.
\end{abstract}

Keywords:3,4'-bis-guanidino; 3-amino-4'-guanidino; diphenyl ether; phenyl pyridyl ether; intramolecular hydrogen bond; cancer cell viability; HL-60; BRAF; apoptosis

\section{Introduction}

Various interlinked signalling pathways are involved in cell proliferation, apoptosis or survival, and these processes are even more relevant in the case of tumour formation [1]. Oncogenic mutations in one of these signalling pathways, the Ras/RAF/MEK/ERK (MAPK/ERK) pathway, are observed frequently in many cancers [2,3]. Additionally, since mutations in RAF kinases are common events, these kinases (i.e., ARAF, BRAF and CRAF) have become very interesting therapeutic targets $[4,5]$.

Most of the protein kinase inhibitors developed so far are ATP competitive and, based on the conformation of the protein kinase they bind to, have been broadly classified as type I (bind to the $\alpha C$-helix-IN/DFG-IN conformation), type II (bind to the $\alpha$ C-helix-IN/DFG-OUT conformation), or type $\mathrm{I} / \mathrm{II}$ (bind to the $\alpha \mathrm{C}$-helix-OUT/DFG-IN conformation) [6]. In addition, there are allosteric inhibitors, known as type III protein kinase inhibitors, which do not compete with ATP. These inhibitors tend 
to exhibit the highest degree of kinase selectivity because they exploit binding sites and regulatory mechanisms unique to particular kinases [7].

Previously, we had identified a 3,4'-bis-guanidinium diphenyl derivative (1, Figure 1$)$ that demonstrated strong cytotoxicity, mediated through induction of apoptosis, in colorectal cancer cells containing wild type(wt)-BRAF and mutated ${ }^{\mathrm{V} 600 \mathrm{E}} \mathrm{BRAF}[8,9]$. Compound 1 also inhibited ERK1/2 signalling, EGFR activation, as well as Src, STAT3 and Akt phosphorylation. We also showed that 1 did not inhibit ATP binding to BRAF, but a radiometric assay of BRAF activity indicated that this was inhibited in vitro. From these studies, we hypothesised that $\mathbf{1}$ could inhibit BRAF as a type III inhibitor. We propose that the positively charged guanidines present in compound $\mathbf{1}$ could interact with the negatively charged phosphates of the ATP present in the active state of all kinases [10].

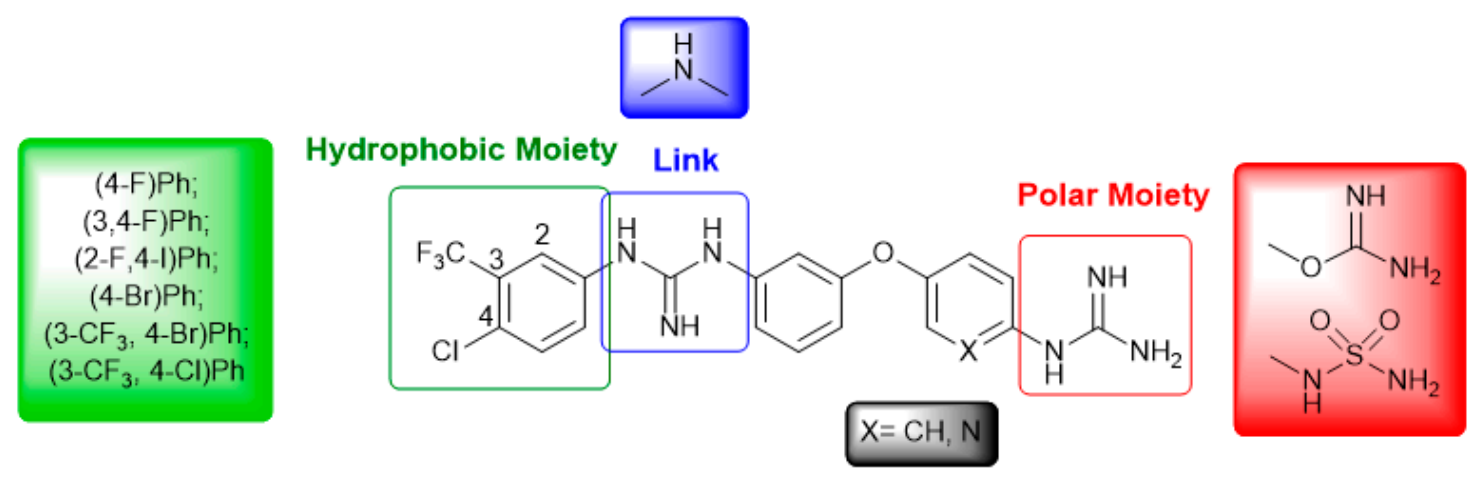

\section{lead compound $1(\mathrm{X}=\mathrm{CH})$}

Figure 1. Structural modifications proposed for the optimization of the compound 1.

Considering that only very recently a crystal structure of a BRAF protein kinase in complex with an ATP analogue (AMP-PCP) and MEK has been resolved (PDB 6U2G) [11], we had previously constructed a model that reproduced an active form of this kinase including ATP to model potential type III inhibitors [12].This in-house model allowed us to explore the potential allosteric inhibition through ATP binding of compound $\mathbf{1}$ and it was considered a good target model for structure-based design when no crystallographic data was available.

Accordingly, in this article, we first present a computational study of a series of guanidine-based di-aromatic systems representative of all the compounds proposed with a simplified version of our in-house active BRAF model to explore their potential as type-III allosteric inhibitors. Additionally, we describe the preparation of the compounds proposed and the study of the anti-proliferative and pro-apoptotic activity on cancerous cell lines as well as their effect on the MAPK/ERK signalling pathway.

\section{Results}

Considering the structure of compound 1 ("link" -blue box-, "polar moiety" -red box- and "hydrophobic moiety" -green box-; see Figure 1), we explored a number of modifications in the different moieties, while maintaining the diaryl ether core due to its versatility and suitability for synthesis. First, several "hydrophobic" substituents have been considered (green box in Figure 1), since in our previously reported computational model [12], this section of the molecule seems to interact with a hydrophobic pocket. Next, based on previous computational studies [9], the effect of the length of the molecule on its activity has been studied by replacing the disubstituted guanidinium in the "link" by a secondary amine (blue box in Figure 1). Additionally, we explored the effect of substituting one of the phenyl rings by a pyridine to lock the orientation of the guanidinium by means of intramolecular hydrogen bonds (IMHBs) [13]. Finally, in the "polar" region, different guanidine surrogates (i.e., isourea and sulfamide) have been tested (red box in Figure 1). 


\subsection{Molecular Modelling Studies}

We had previously reported the docking of compound $\mathbf{1}$ into our in-house ATP-containing BRAF model [12]; here, we are using a simplified model containing triphosphate (TP) instead of ATP since the interactions of interest only occur with the phosphates and adjacent hydrophobic pocket. Thus, in order to validate our TP-containing BRAF model, we first docked compound 1 (Figure 1) and considering that similar outcomes were observed, we used the TP-containing structure and similar conditions for the rest of the computational studies. Accordingly, a set of representative structures of all the compounds proposed were selected; compound 2 contains a pyridine instead of a phenyl ring as it was in compound $\mathbf{1}$, in compound $\mathbf{3}$ the di-substituted guanidine of $\mathbf{1}$ has been changed to a secondary amine and compound 4 shows both modifications (Figure 2).<smiles>NC(=[NH2+])Nc1cccc(Oc2cccc(NC(=[NH2+])Nc3ccc(Cl)c(C(F)(F)F)c3)c2)c1</smiles>

2<smiles>NC(=[NH2+])Nc1ccc(Oc2cccc(NC3(c4ccc(Cl)c(C(F)(F)F)c4)CCC3)c2)cc1</smiles>

3<smiles>NC(=[NH2+])Nc1cccc(NC2CCCC2)c1Oc1cccc(NC(=O)c2ccc(Cl)c(C(F)(F)F)c2)c1</smiles>

4

Figure 2. Structures of the proposed new derivatives of $\mathbf{1}$ (compounds $\mathbf{2 ,} 3$ and $\mathbf{4}$ ), which docking to the in-house triphosphate (TP)-containing BRAF simplified model was studied.

As in our previous modelling studies [12], we found that compound 1 interacts with BRAF through an allosteric region found near the ATP binding site and with the TP system. The main interactions established involved bifurcated hydrogen bonds (HBs) between the mono-substituted guanidinium and two negatively charged $\mathrm{O}$ atoms of a phosphate $(\mathrm{NH} \cdots \mathrm{O}$ distances: 1.6, 2.9 and $2.7 \AA$, Figure S1) and a parallel HB interaction between the di-substituted guanidinium and the carboxylate of Glu648 ( $\mathrm{NH}^{\cdots}$ O distances: of 2.0 and 2.6 A, Figure S1). Both sets of HBs are reinforced by ionic interactions due to the charged nature of guanidinium, phosphate and carboxylate groups. Additionally, interactions are observed in the lipophilic pocket with the $\left(4-\mathrm{Cl}_{3} 3-\mathrm{CF}_{3}\right) \mathrm{Ph}$ moiety; thus, the $\mathrm{CF}_{3}$ group interacts with Met620 and the $\mathrm{Cl}$ with Trp619 (Figure S1).

Likewise, when derivative 2 is docked into the TP-BRAF simplified model, it forms ionically reinforced bifurcated HBs between the mono-substituted guanidinium and two negatively charged $\mathrm{O}$ atoms of TP (Figure 3). Likewise, a bifurcated HB interaction between the di-substituted guanidinium and Glu648 and van der Waals contacts at the lipophilic pocket with the (4-Cl,3-CF $) \mathrm{Ph}$ moiety were also found for compound 2 (Figure 3). The newly introduced pyridine seems to form a HB with Asn137 as well as an IMHB that locks the mono-substituted guanidinium (Figure 3). This conformational restriction could result in increased affinity.

Replacement of the di-substituted guanidine by an -NH- leads to a significantly shorter molecule as in system 3 (Figure 2). Upon docking to the TP-containing simplified BRAF, we observed that the mono-substituted guanidinium still forms the expected bifurcated HBs. Compound 3 also fits within the hydrophobic pocket of the target establishing weaker contacts (longer interaction distances) with Met620 and Trp619. Additionally, the newly introduced -NH- group forms a HB with one of the O atoms of Glu648 (Figure S2).

Finally, the docking study of compound 4 (Figure 2) into the aforementioned target reproduce the results observed for the mono-substituted guanidinium pyridine system in analogue 2 by establishing bifurcated HBs with the TP, IMHB between guanidinium and pyridine as well as contacts between the 
pyridine $\mathrm{N}$ and Asn137. Additionally, as the $-\mathrm{NH}$ - shortens the structure, similar interactions to those seen for compound 3 are observed, i.e., the -NH- group forms a HB with Glu648 and contacts within the hydrophobic pocket are found (Figure S3).

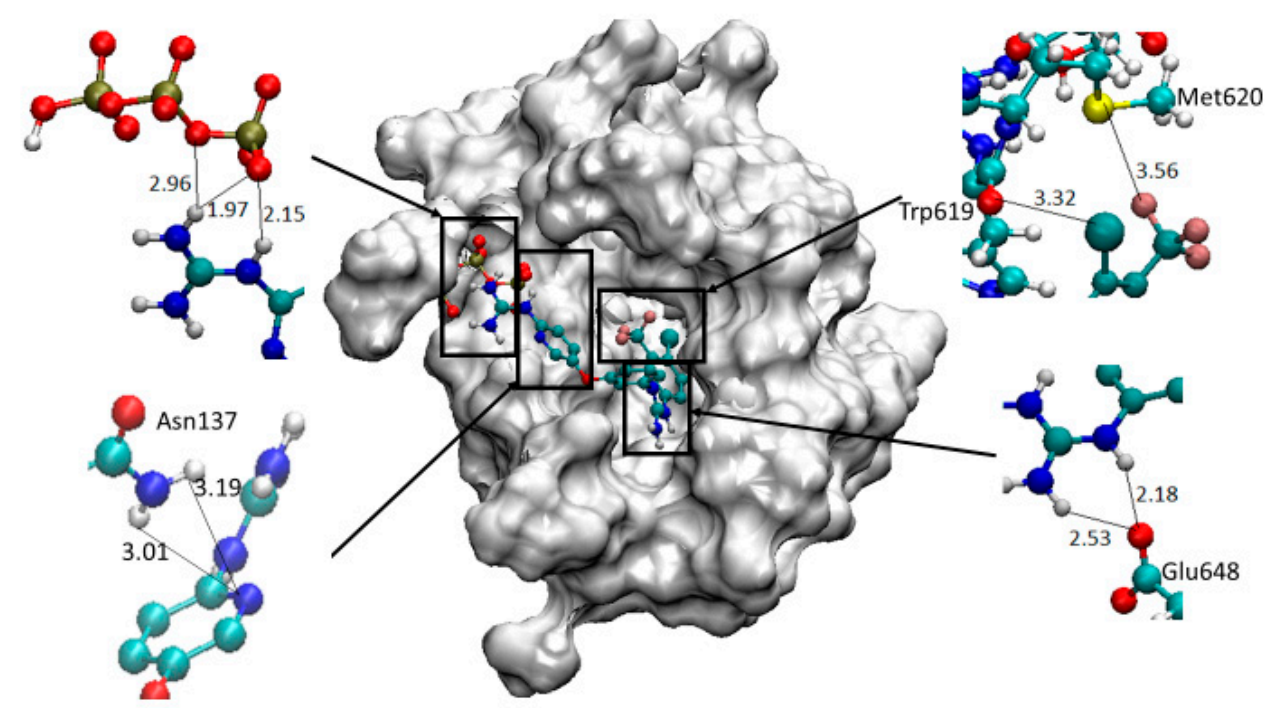

Figure 3. Docking of derivative 2 in the TP-containing BRAF simplified model indicating the bifurcated (up left, bottom left and right) and single (up right) hydrogen bond (HB) interactions observed. Distances are expressed in $\AA$.

All this work was carried out prior to the recent publication of the crystal structure of BRAF containing an analogue of ATP (AMP-PCP) [11], and in order to validate our in-house BRAF-ATP model [12] we now superimposed both the reported crystal structure with our model finding an RMSD of $2.53 \AA$ between them and with both ATP-like systems occupying the same pocket and with very similar orientations (Figures S4 and S5). This level of similarity gives us confidence on the docking studies performed with our BRAF-TP model.

The G-scores obtained for the best-poses obtained were very similar for the four compounds studied (around $-7.7 \mathrm{kcal} / \mathrm{mol}$ ); hence, the interaction with the target was favoured in all the cases but did not help to discriminate among the four compounds. In summary, according to the docking studies all the compounds proposed seem to establish favourable interactions with BRAF, suggesting a possible type III allosteric binding.

\subsection{Synthesis}

The synthesis of the analogues of compound 1,3,4'-bis-guanidino diphenyl ethers 5-11, required the preparation of the corresponding $N$-aryl- $N^{\prime}$-Boc-protected thioureas (12-16) following a procedure previously developed in the group starting from $N, N^{\prime}$-bis-(tert-butoxycarbonyl)thiourea 17 (Scheme 1) [8]. Given the diverse electron-withdrawing effect of differently substituted commercially available anilines, different yields of the corresponding thioureas 12-16 were obtained (37-57\%, see details in ESI). The corresponding Boc-protected mono-guanidines 18 and 19 were prepared by reaction of commercially available 3,4'-dianiline ether 20 and $N, N^{\prime}$-bis-(tert-butoxycarbonyl)thiourea 17 in the presence of $\mathrm{HgCl}_{2}$ and $\mathrm{NEt}_{3}$ yielding 18 and 19 as a mixture that was separated by column chromatography in good and moderate yields (Scheme 1) [14].

Next, the $N$-aryl- $N$ '-Boc-protected thioureas 12-16 were reacted with $\mathbf{1 8}$ or $\mathbf{1 9}$ under our standard conditions $\left(\mathrm{HgCl}_{2}\right.$ and $\left.\mathrm{NEt}_{3}\right)$ to yield the corresponding Boc-protected 3-arylguanidino-4'-guanidino (21-25) and 3-guanidino-4'-arylguanidino (26-27) diphenyl ether derivatives (Scheme 1).

In order to prepare compound 3 and its analogues 28-30, the nitrophenyl precursor 31 was synthesised by a $S_{N} A r$ reaction between commercially available 3-aminophenol and 1-fluoro-4nitrobenzene [15]. Compounds 32-35 were synthesized using a Buchwald-Hartwig cross-coupling; 
the success of this reaction depends on variables such as ligand, Pd source, base and solvent [16]. The conditions chosen $\left(\mathrm{Pd}_{2}(\mathrm{dba})_{3} 3 \mathrm{~mol} \%\right.$, BINAP $3 \mathrm{~mol} \%$, NaOtBu 1.4 eq. in dry toluene $\left(2 \mathrm{~mL} \mathrm{mmol}^{-1}\right)$ at $90{ }^{\circ} \mathrm{C}$ ) afforded the proposed compounds $32-35$ in high yields $(62-87 \%$, Scheme 2$)$.

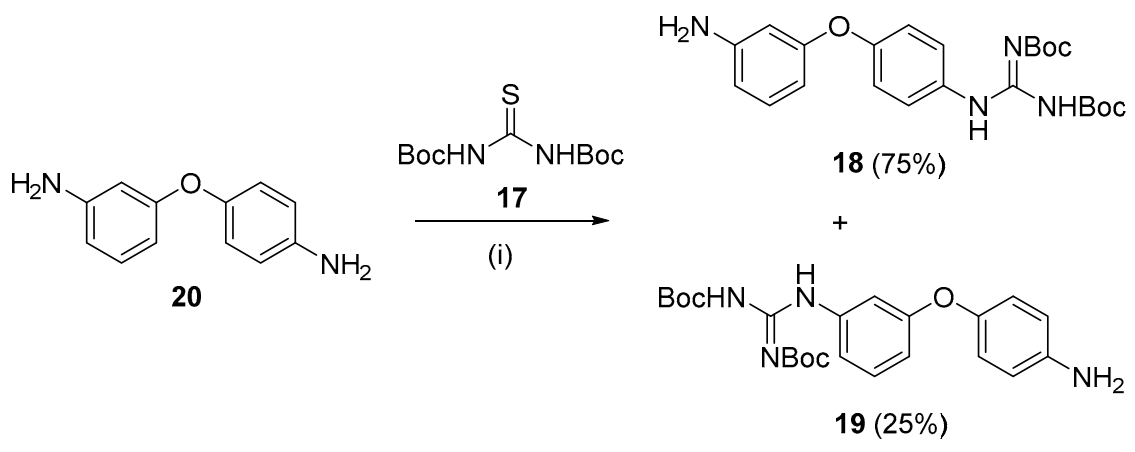

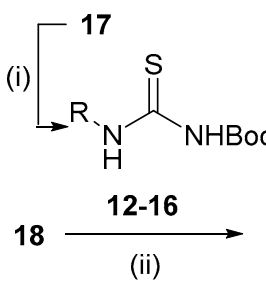

12, $\mathrm{R}=(4-\mathrm{F}) \mathrm{Ph}(42 \%)$

13, $\mathrm{R}=(3,4-\mathrm{diF}) \mathrm{Ph}(57 \%)$

$14, \mathrm{R}=(2-\mathrm{F}, 4-\mathrm{I}) \mathrm{Ph}(57 \%)$

15, $\mathrm{R}=(4-\mathrm{Br}) \mathrm{Ph}(43 \%)$

16, $\mathrm{R}=\left(3-\mathrm{CF}_{3}, 4-\mathrm{Br}\right) \mathrm{Ph}(37 \%)$<smiles>[R]NC(=N)Nc1cccc(Oc2ccc(NC(=N)NC(=N)O[R16]([H])(C)C)cc2)c1</smiles>

21-25 (36-61\%)
5, $\mathrm{R}=(4-\mathrm{F}) \mathrm{Ph}(76 \%)$

6, $\mathrm{R}=(3,4-\mathrm{diF}) \mathrm{Ph}(90 \%)$

7, $R=(2-F, 4-I) P h(83 \%)$

8, $\mathrm{R}=(4-\mathrm{Br}) \mathrm{Ph}(87 \%)$

9, $\mathrm{R}=\left(3-\mathrm{CF}_{3}, 4-\mathrm{Br}\right) \mathrm{Ph}(89 \%)$

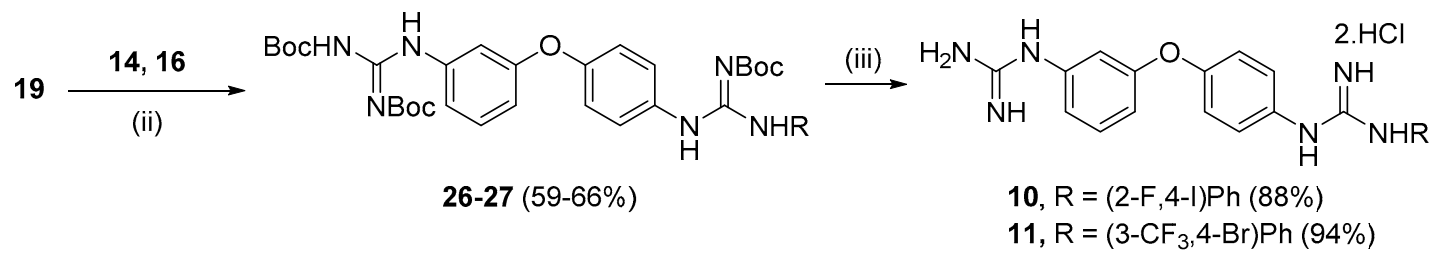

Conditions: (i) $\mathrm{HgCl}_{2}, \mathrm{NEt}_{3}, \mathrm{CH}_{2} \mathrm{Cl}_{2} 0^{\circ} \mathrm{C}$ to rt; (ii) $\mathrm{NaH}$, TFAA, THF, $0^{\circ} \mathrm{C}$ to rt; (iii) $0.2 \mathrm{M} \mathrm{HCl} /$ dioxane, $55^{\circ} \mathrm{C}, 8 \mathrm{~h}$.

Scheme 1. Preparation of mono-substituted 3,4'-bis-guanidinium diphenyl ether derivatives.

With the intention of probing the effect of branching in the diphenyl ether core, we prepared the fluoro derivative 36 for which we synthesised precursor 37 by using commercially available 3-bromo -5-fluorophenol that in the presence of $\mathrm{K}_{2} \mathrm{CO}_{3}$ and DMF quantitatively reacted with 4-fluoronitrobenzene. Then, 37 was used for the Buchwald-Hartwig coupling with 4-chloro-3-(trifluoromethyl)aniline to afford compound 38 in good yield (Scheme 2).

Precursors 32-35 and $\mathbf{3 8}$ were then subjected to selective reduction of the nitro group to the amine that will serve as handle for the introduction of the guanidine moiety. Nitro reduction of compounds 34 and 35 was achieved using catalytic hydrogenation $\left(\mathrm{H}_{2}, \mathrm{Pd} / \mathrm{C} 10 \mathrm{~mol} \%\right)$ yielding aniline derivatives 41 and 42; however, in the case of chloro-derivatives 32,33 , and 38 , selective reduction was achieved with the use of tin(II) chloride dihydrate $\left(\mathrm{SnCl}_{2} \cdot 2 \mathrm{H}_{2} \mathrm{O}\right)$ to produce anilines 39,40 , and 43 [17]. Utilising our standard conditions, a guanidine moiety was introduced affording Boc-protected mono-guanidines 44-48 (Scheme 2).

In order to prepare the 3,4'-bis-guanidino phenyloxypyridines 2, 4, and 49-52, the starting 5-(3aminophenoxy)pyridin-2-amine (53) was synthesized. Thus, $\mathrm{S}_{\mathrm{N}} \mathrm{Ar}$ between 5-bromo-2-nitropyridine and 3-nitrophenol yielded the previously reported mixture of isomers (54 and 55) [18], which were 
separated by chromatography. Further hydrogenation of $\mathbf{5 4}$ gave the desired product $\mathbf{5 3}$ in good yield (Scheme 3) $[15,19]$.
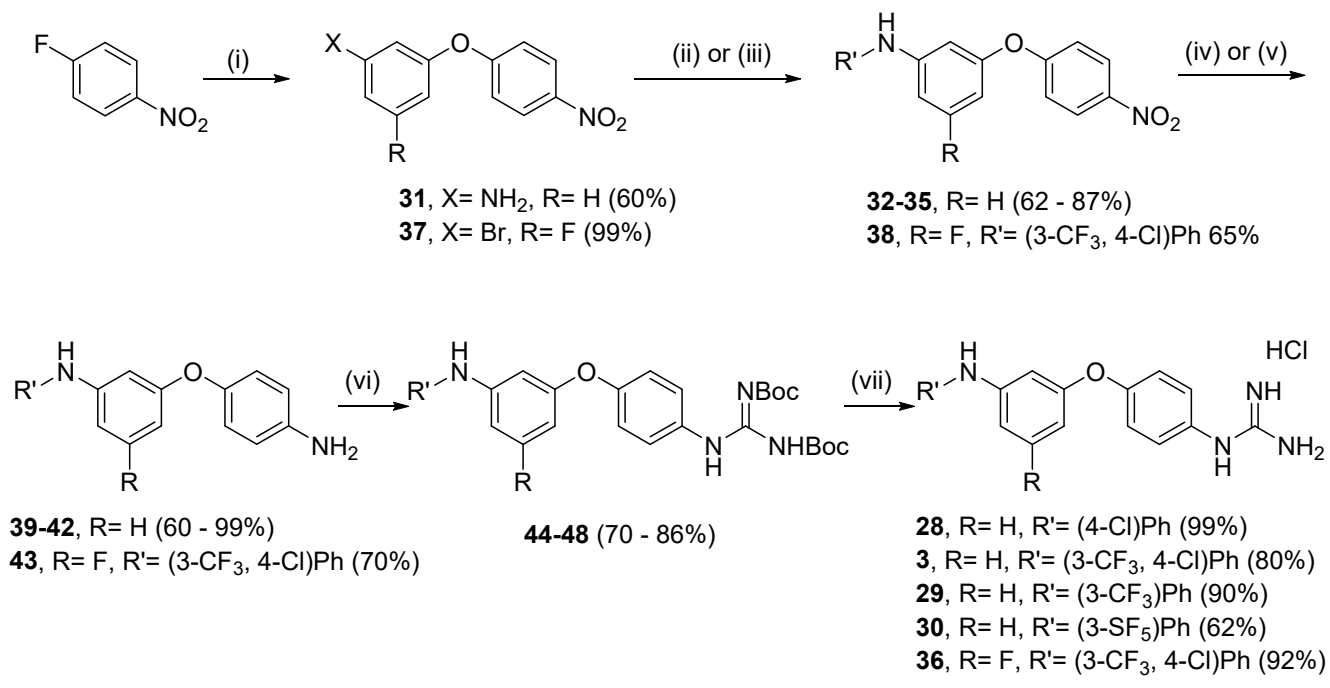

Conditions: (i) 3-Aminophenol or, for 37, 3-bromo-5-fluorophenol, $\mathrm{K}_{2} \mathrm{CO}_{3}$, DMF, $80^{\circ} \mathrm{C}, 12 \mathrm{~h}$; (ii) R-Br, $\mathrm{Pd}_{2}(\mathrm{dba})_{3}$, BINAP, $\mathrm{NaO}{ }^{\mathrm{t}} \mathrm{Bu}$, toluene, $90^{\circ} \mathrm{C}, 24 \mathrm{~h}$; (iii) for 38, 4-chloro-3-(trifluoromethyl)aniline, $\mathrm{Pd}_{2}(\mathrm{dba})_{3}$, BINAP, $\mathrm{NaO}{ }^{\mathrm{t} B u}$, toluene, $90^{\circ} \mathrm{C} 24 \mathrm{~h}$; (iv) $\mathrm{H}_{2}, \mathrm{Pd} / \mathrm{C}, \mathrm{EtOH}$, rt, $24 \mathrm{~h}$; (v) $\mathrm{SnCl}_{2} \cdot 2 \mathrm{H}_{2} \mathrm{O}$, EtOAc, $70{ }^{\circ} \mathrm{C}, 3 \mathrm{~h}$; (vi) $\mathrm{N}, N^{\prime}$-bis-(tert-butoxycarbonyl)-S-methylisothiourea, $\mathrm{HgCl}_{2}, \mathrm{NEt}_{3}, \mathrm{CH}_{2} \mathrm{Cl}_{2}, 0^{\circ} \mathrm{C}$ to rt; (vii) $0.2 \mathrm{M}$ $\mathrm{HCl} /$ dioxane, $55^{\circ} \mathrm{C}, 8 \mathrm{~h}$.

Scheme 2. Preparation of 3-amino, 4 '-guanidine diphenyl ether derivatives.

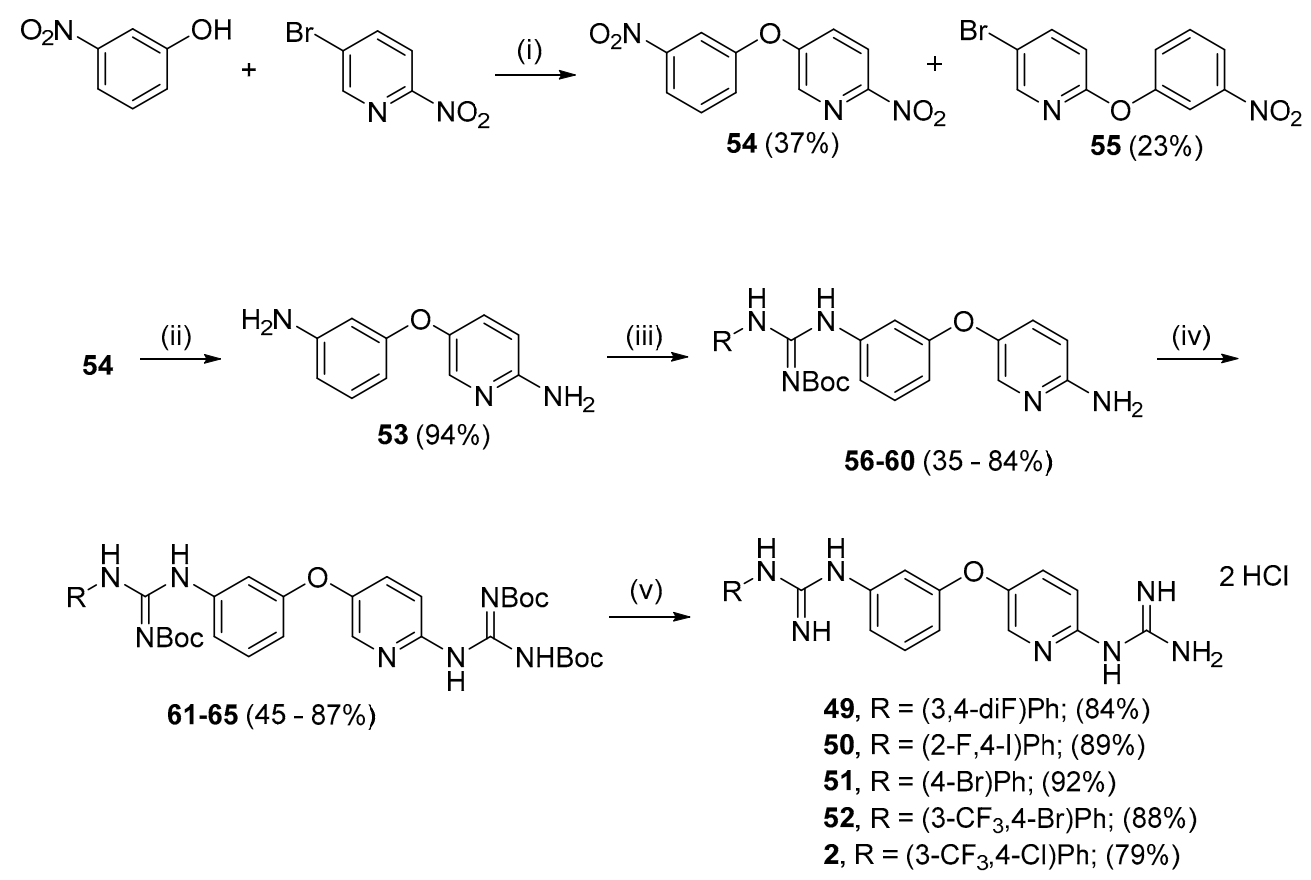

Conditions: (i) $\mathrm{Cs}_{2} \mathrm{CO}_{3}$, DMF, $80^{\circ} \mathrm{C}, 12 \mathrm{~h}$; (ii) $\mathrm{H}_{2}$, Pd/C, EtOH/THF/EtOAc, rt, 24 h; (iii) Boc-protected thioureas 12-16, $\mathrm{HgCl}_{2}, \mathrm{NEt}_{3}, \mathrm{CH}_{2} \mathrm{Cl}_{2} 0^{\circ} \mathrm{C}$ to rt, $12 \mathrm{~h}$; (iv) Boc-protected S-methylisothiourea, $\mathrm{HgCl}_{2}$, $\mathrm{NEt}_{3}, \mathrm{CH}_{2} \mathrm{Cl}_{2} \mathrm{O}^{\circ} \mathrm{C}$ to rt, $12 \mathrm{~h}$; (v) $0.2 \mathrm{M} \mathrm{HCl} /$ dioxane, $55^{\circ} \mathrm{C}, 8 \mathrm{~h}$.

Scheme 3. Preparation of 3,4'-bis-guanidine pehylpyridyl ether derivatives. 
Compound 53 was then reacted with Boc-protected thioureas 12-16, under our standard conditions to yield Boc-protected mono-guanidines 56-60 [8]. Subsequent guanidylation at position 2 of the pyridine ring was carried out with commercial $N, N^{\prime}$-bis-(tert-butoxycarbonyl)-S-methylisothiourea to obtain Boc-protected compounds 61-65 (Scheme 3).

Preparation of the corresponding precursors for compound 4 required the synthesis of 3-((6nitropyridin-3-yl)oxy)aniline 66 through a $S_{N} A r$ between 5-bromo-2-nitropyridine and 3-aminophenol (Scheme 4).<smiles>Nc1cccc(O)c1</smiles><smiles>[R16]c1cccc(Nc2cccc(Oc3ccc([N+](=O)[O-])nc3)c2)c1</smiles>

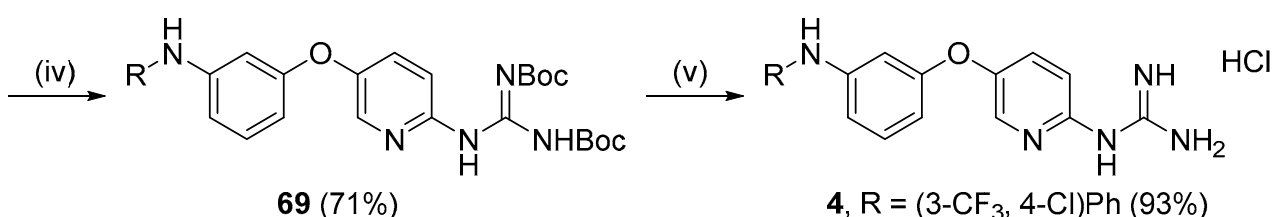

Conditions: (i) $\mathrm{Cs}_{2} \mathrm{CO}_{3}, \mathrm{DMF}, 80^{\circ} \mathrm{C}, 12 \mathrm{~h}$; (ii) R-Br, $\mathrm{Pd}_{2}(\mathrm{dba})_{3}$, Xantphos, $\mathrm{Cs}_{2} \mathrm{CO}_{3}$, toluene, $90^{\circ} \mathrm{C} 24 \mathrm{~h}$; (iii) $\mathrm{SnCl}_{2} \cdot 2 \mathrm{H}_{2} \mathrm{O}$, EtOAc, $70{ }^{\circ} \mathrm{C}, 3 \mathrm{~h}$; (iv) Boc-protected S-isomethylthiourea, $\mathrm{HgCl}_{2}, \mathrm{NEt}_{3}, \mathrm{CH}_{2} \mathrm{Cl}_{2}, 0^{\circ} \mathrm{C}$ to rt; (v) $0.2 \mathrm{M}$ $\mathrm{HCl} /$ dioxane, $55^{\circ} \mathrm{C}, 8 \mathrm{~h}$.

Scheme 4. Preparation of 3-amino-4'-guanidine phenylpiridyl ether derivatives.

Preparation of the arylanilino nitropyridine 67 was next attempted following the previous conditions described for the synthesis of 32-35 and 38 with poor results. However, Pd-catalysed reaction using of Xantphos and $\mathrm{Cs}_{2} \mathrm{CO}_{3}$ yielded compound 67 in good yield. Next, $\mathrm{SnCl}_{2} \cdot 2 \mathrm{H}_{2} \mathrm{O}$ reduction conditions afforded compound 68 that was then subjected to guanidylation using N,N'-bis-(tert-butoxycarbonyl)-S-methylisothiourea to obtain Boc-protected compound 69 (Scheme 4).

With the aim of introducing diversity to the "polar" moiety of compound 3, we also explored the substitution of the guanidinium system by an isouronium cation or a sulfamide (Scheme 5). Thus, preparation of the 3-anilino-4'-O-isourea phenylozybenzene derivative $\mathbf{7 0}$ involved the use of the previously synthesised compound 71 [20] as starting material for the synthesis of the intermediate 72 through the mentioned conditions for a Buchwald-Hartwig coupling $\left(\mathrm{Pd}_{2}(\mathrm{dba})_{3}\right.$, Xantphos, $\mathrm{Cs}_{2} \mathrm{CO}_{3}$, toluene, $90^{\circ} \mathrm{C}, 24 \mathrm{~h}$ ).

Compound 72 was then deprotected with montmorillonite KSF to obtain the corresponding phenol 73, which $\mathrm{OH}$ was then amidylated using standard conditions previously described by us [20] to yield the corresponding Boc-protected isouronium 74 (Scheme 5). Sulfamide 75 was synthesised by treating amine $\mathbf{4 0}$ with sulfamoyl chloride (previously prepared from chlorosulfonyl isocyanate and formic acid [21,22]) to afford compound 75 in good yield (Scheme 5).

All Boc-protected precursors were deprotected using $\mathrm{HCl} 4 \mathrm{M}$ /dioxane to yield compounds 2-11, 28-30, 36, 49-52 (Schemes 1-4) and $\mathrm{SnCl}_{4}$ to obtain compound 70. The purity of all the final hydrochloride salts was determined by HPLC, where a minimum purity of $95 \%$ was required before proceeding to biological testing (ESI). 
<smiles>[R]Nc1cccc(Oc2ccc(OC3CCCCO3)cc2)c1</smiles><smiles>[R]Nc1cccc(Oc2ccc(OC(=N)N)cc2)c1</smiles><smiles>[R]Nc1cccc(Oc2ccc(N)cc2)c1</smiles>

Conditions: (i) R-Br, Pd2(dba)3, Xantphos, $\mathrm{Cs}_{2} \mathrm{CO}_{3}$, toluene, $90^{\circ} \mathrm{C}, 24 \mathrm{~h}$; (ii) $\mathrm{KSF}, \mathrm{MeOH}, 50^{\circ} \mathrm{C} ; 4$ h; (iii) Boc-protected S-methylisothiourea, $\mathrm{HgCl}_{2}, \mathrm{NEt}_{3}, \mathrm{CH}_{2} \mathrm{Cl}_{2}, 0^{\circ} \mathrm{C}$ to rt; (iv) $\mathrm{SnCl}, \mathrm{H}_{2} \mathrm{O}$, EtOAc, rt, $1 \mathrm{~h}$; (v) $\mathrm{NEt}_{3}, \mathrm{CH}_{2} \mathrm{Cl}_{2}$, rt, $2 \mathrm{~h}$.

Scheme 5. Preparation of 3-amino-4'-isourea and 3-amino-4'-sulfamido diphenyl ether derivatives.

\subsection{Predicted Physicochemical and In Vitro ADME Properties}

Attention to physicochemical and pharmacokinetic properties of active molecules should be given at the early stages of their design in order to shorten their development to a drug. However, these properties are not always easy to be experimentally evaluated and, hence, computational approaches represent a good solution to get a general idea of the potential of compounds as drugs. Thus, to assess the drug-likeness of the compounds studied, we utilized SwissADME [23] and ChemAxon's Marvin [24] to computationally evaluate the mentioned properties and the calculated values are reported in Tables S1-S3 (ESI). All proposed compounds have a molecular weight (MW) $<500 \mathrm{Da}$, except for 3,4'-bis-guanidine phenyloxybenzenes 7, 9, 10 and $\mathbf{1 1}$ or phenyloxypyridines $\mathbf{5 0}$ and 52, in which the MW exceeds by 7-10 units this threshold; such small exceptions are considered acceptable [25]. The consensus $\log \mathrm{P}_{\mathrm{o} / \mathrm{w}}$ [23] for all synthesised compounds is reported in Table S2 (ESI) indicating that, overall, all the compounds have a $\log \mathrm{P}<5$. Topological Polar Surface Area (TPSA), which is an indicator of HB formation and a commonly used metric for a drug's ability to permeate cells, was calculated for all the synthesised molecules and all of them have values $<140 \AA^{2}$, which is the limit suggested in the literature for poor cell membrane permeation [25-27]. Specifically, shorter 3-amino-4'-guanidines have much lower TPSA (80-100 $\left.\AA^{2}\right)$ than 3,4'-bis-guanidinium analogues $\left(120-135 \AA^{2}\right)$.

The BOILED egg graph presents a correlation between calculated $\log P$ and calculated TPSA and is an intuitive simultaneous prediction of two key ADME parameters, i.e., the passive gastrointestinal (GI) absorption and brain access (blood brain barrier, BBB) $[23,28]$. Compounds that fall into the white part of the graph are likely to undergo GI absorption and those that fall into the yellow part of the graph are likely to be brain permeant. Accordingly, all of our derivatives could undertake passive GI absorption (except pentafluorosulfanyl derivative $\mathbf{3 0}$ and sulfamide 75 ), but none of them can cross the BBB (Figure S6). In addition, SwissADME enables the estimation for a chemical to be a substrate of the permeability glycoprotein (P-gp), which is the most important ATP-binding cassette transporter responsible for an active efflux through biological membranes, e.g., from the GI wall to the lumen or exiting the brain) $[28,29]$. Thus, as reported in the legend of Figure S6, red dots indicate that all of our compounds, except compounds 49-51 (blue dots), are non-substrates of P-gp (Table S3). 
The theoretical $\mathrm{pK}_{\mathrm{aH}}$ values of all the synthesised compounds calculated with Marvin are reported in Table S1. The results indicate that exchanging the para mono-substituted guanidinium (compound 3) by an isouronium moiety (compound 70) results in a $\mathrm{pK}_{\mathrm{aH}}$ decrease (less basic molecule). Interestingly, the pyridine derivatives (49-52, 2 and 4) show lower $\mathrm{pK}_{\mathrm{aH}}$ values than their diphenyl counterparts (6-9, 1 and 3, respectively), probably due to the IMHB formed between the para guanidinium and the pyridine ring.

Solubility is not an easy parameter to model in silico, but SwissADME gives an estimation of the solubility class based on three predictors, two topological and one fragmental method [23]. According to this program, all our molecules are poorly soluble in aqueous environments (Table S2). For the preclinical evaluation of our molecules, their solubility in EtOH/DMSO is still acceptable, but future work will have to be carried out to achieve full water solubility.

Other numerical descriptors are used to assess drug-likeness including the number of HB acceptors and donors (HBAs and HBDs) or the number of rotatable bonds (RotB) and the results obtained for this set of compounds are shown in Table S1 [27]. According to these descriptors, in general, all studied compounds fulfil drug-like conditions.

\subsection{Biochemical Studies}

\subsubsection{Cell Viability in Cancerous and Non-Cancerous Cell Lines}

Cell viability and proliferation assays were used to evaluate the in vitro cytotoxicity of all synthesised compounds in a variety of different cancer cell lines using the alamarBlue ${ }^{\circledR}$ viability assay and the results are presented in Tables 1 and 2. The sensitivity of cancer cells to drugs can often be compromised by PIK3CA, Ras and BRAF mutations. To determine whether such mutations are critical to the efficacy of our new compounds we tested them in a range of cancerous cell lines expressing different mutations. Firstly, we used the HL-60 (human promyelocytic leukaemia, NRas mutated) cell line for general cytotoxicity screening of all compounds. Next, the most active derivatives were studied in MCF-7 (breast adenocarcinoma, Ras/RAF wild type, and PIK3CA mutant), HeLa (cervical carcinoma, Ras/RAF and PIK3CA wild type), as well as HCT-116 and HKH-2 (colorectal carcinoma, KRas mutant and mutated KRas disrupted, respectively) cell lines [8]. Lastly, toxicity against MCF-10A, which is a non-tumorigenic epithelial cell line, was also assessed for one of the most promising compounds (4). The graphs representing the viability results with the HL-60, MCF-7, HeLa, HCT-116, and HKH-2 cancer cell lines for compound 1 and derivatives 2, 3, and 4 are shown in Figures S7-S10 (ESI). Sorafenib (a known inhibitor of protein kinases including VEGFR, PDGFR and RAF [30,31]) was used as a positive control in all viability assays.

Table 1. Effect on the viability of HL-60 cells $\left(\mathrm{IC}_{50}, \mu \mathrm{M}\right)$ of compounds 1-11, 28-30, 36, 49-52, 70, 75 and sorafenib with alamarBlue ${ }^{\circledR}$ assays.

\begin{tabular}{|c|c|c|c|c|c|}
\hline Compounds. & $\begin{array}{c}\text { HL-60 } \\
\text { IC }_{50} \pm \text { SEM }\end{array}$ & Compounds. & $\begin{array}{c}\text { HL-60 } \\
\mathrm{IC}_{50} \pm \mathrm{SEM}\end{array}$ & Compounds. & $\begin{array}{c}\text { HL-60 } \\
\text { IC }_{50} \pm \text { SEM }\end{array}$ \\
\hline Sorafenib & $2.53 \pm 0.68$ & 8 & $15.26 \pm 1.98$ & 49 & $11.61 \pm 0.27$ \\
\hline $\mathbf{1}^{7}$ & $9.72 \pm 0.9$ & 9 & $2.07 \pm 0.33$ & 50 & $8.33 \pm 0.32$ \\
\hline 2 & $2.36 \pm 0.14$ & 10 & $8.85 \pm 0.55$ & 51 & $9.37 \pm 0.54$ \\
\hline 3 & $3.08 \pm 0.15$ & 11 & $10.99 \pm 0.64$ & 52 & $1.53 \pm 0.23$ \\
\hline 4 & $3.48 \pm 0.28$ & 28 & $7.50 \pm 0.05$ & 70 & $4.22 \pm 0.04$ \\
\hline 5 & $>100$ & 29 & $4.64 \pm 0.83$ & 75 & $9.14 \pm 0.69$ \\
\hline 6 & $>100$ & 30 & $3.23 \pm 0.36$ & & \\
\hline 7 & $8.63 \pm 0.51$ & 36 & $4.07 \pm 0.10$ & & \\
\hline
\end{tabular}

(a) Cells were seeded at a density of $2 \times 10^{5}$ cells/mL (HL-60) in a 96-well plate and treated with different concentrations of the compounds dissolved in EtOH or DMSO (1\% v/v and $0.1 \% v / v$, respectively). Sorafenib was used as a reference and tested in the same manner. Once treated, cells were incubated for $72 \mathrm{~h}$ at $37{ }^{\circ} \mathrm{C}$ after which they were treated with alamarBlue ${ }^{\circledR}$ and left in darkness in an incubator for $5 \mathrm{~h}$. The resulting fluorescence $\left(\lambda_{\text {excitation }}=544 \mathrm{~nm}, \lambda_{\text {emission }}=590 \mathrm{~nm}\right)$ was read using a plate reader from which percentage viability was calculated. $\mathrm{IC}_{50}$ values were calculated using Prism GraphPad Prism software from at least three independent experiments performed in triplicate. Highlighted in grey are those $\mathrm{IC}_{50}$ values better than or similar to the control used, Sorafenib. 
Table 2. Effect in viability of MCF-7, HeLa, HCT116, and HKH-2 cancer cells $\left(\mathrm{IC}_{50}, \mu \mathrm{M}\right)$ of compounds 1-4, 70 and sorafenib on the alamarBlue ${ }^{\circledR}$ assays.

\begin{tabular}{ccccc}
\hline Compds. & $\begin{array}{c}\text { MCF-7 } \\
\text { IC } 5 \mathbf{5 0} \pm \text { SEM }\end{array}$ & $\begin{array}{c}\text { HeLa } \\
\text { IC }\end{array}$ 50 \pm SEM & $\begin{array}{c}\text { HCT116 } \\
\text { IC }_{50} \pm \text { SEM }\end{array}$ & $\begin{array}{c}\text { HKH-2 } \\
\text { IC }_{50} \pm \text { SEM }\end{array}$ \\
\hline Sorafenib & $3.07 \pm 0.10$ & $4.59 \pm 0.45$ & $6.79 \pm 0.18$ & $4.43 \pm 0.39$ \\
$\mathbf{1}$ & $9.30 \pm 1.87$ & $9.48 \pm 0.16$ & $9.96 \pm 0.60$ & $19.18 \pm 0.84$ \\
$\mathbf{2}$ & $4.91 \pm 1.04$ & $4.87 \pm 0.27$ & $7.29 \pm 0.53$ & $8.09 \pm 0.78$ \\
$\mathbf{3}$ & $2.02 \pm 0.27$ & $4.33 \pm 0.54$ & $15.88 \pm 2.73$ & $10.34 \pm 0.74$ \\
$\mathbf{4}$ & $3.73 \pm 0.35$ & $1.33 \pm 0.08$ & $4.59 \pm 0.40$ & $2.88 \pm 0.15$ \\
$\mathbf{7 0}$ & $7.32 \pm 0.35$ & & & \\
\hline
\end{tabular}

(a) Cells were seeded at a density of $25 \times 10^{3}$ cells $/ \mathrm{mL}$ (MCF-7 and HeLa) or $1 \times 10^{5}$ cells $/ \mathrm{mL}$ (HCT-116 and HKH-2) in a 96-well plate and treated with different concentrations of the compounds dissolved in EtOH or DMSO (1\% $v / v$ and $0.1 \% v / v$, respectively). Sorafenib was used as a reference and tested in the same manner. Once treated, cells were incubated for $72 \mathrm{~h}$ at $37^{\circ} \mathrm{C}$ after which they were treated with alamarBlue ${ }^{\circledR}$ and left in darkness in an incubator for $5 \mathrm{~h}$. The resulting fluorescence $\left(\lambda_{\text {excitation }}=544 \mathrm{~nm}, \lambda_{\text {emission }}=590 \mathrm{~nm}\right)$ was read using a plate reader from which percentage viability was calculated. $\mathrm{IC}_{50}$ values were calculated using Prism GraphPad Prism software from at least three independent experiments performed in triplicate. Highlighted in grey are those $\mathrm{IC}_{50}$ values better than or similar to the control used, Sorafenib, in each particular cell line.

The results obtained with the HL-60 cell line (Table 1) for the 3,4'-bis-guanidine derivatives 5-11 show, in general, more cytotoxicity than the previously tested compound 1 [8]. However, compounds 5 and 6, which carry 3-F and 3,4-diF phenyl groups, respectively, give $\mathrm{IC}_{50}$ values above $100 \mu \mathrm{M}$; this drop in activity is a clear indication of the importance of the size and nature of the substituents on the phenyl ring [32]. The presence of 2-F and 4-I substituents in the hydrophobic moiety of derivative 7 resulted in an $\mathrm{IC}_{50}$ value $(8.63 \mu \mathrm{M})$ similar to 1 . Substitution of the $4-\mathrm{Cl}$ in compound 1 by a $4-\mathrm{Br}$ (i.e., compound 9), gave a four-fold increase in activity, indicating that the halogen in this hydrophobic moiety could establish a halogen-bond with a Lewis base in the protein binding site. Additionally, compound $\mathbf{8}$ had decreased activity because of the absence of the $3-\mathrm{CF}_{3}$ substituent; this is an indication that such a big and polarized halogen atom can only result in a beneficial increment in activity when a bulky lipophilic substituent as $\mathrm{CF}_{3}$ is present at position 3 .

Cytotoxicity results of compounds $\mathbf{1 0}$ and $\mathbf{1 1}$ (lipophilic moiety in $4^{\prime}$-position of the phenyloxyphenyl core instead of the 3-position) with HL-60 cells show that compound $\mathbf{1 0}$ maintains a similar $\mathrm{IC}_{50}$ value as 7; however, $\mathbf{1 1}$ has a reduction of activity compared to $\mathbf{9}$.

Compound 3, which is a shorter version of $\mathbf{1}$ (-NH- link instead of a di-substituted guanidinium) shows increased cytotoxicity in HL-60 cells $\left(\mathrm{IC}_{50}=3.08 \mu \mathrm{M}\right)$. Similar to what was observed for the $3,4^{\prime}$-bis-guanidine derivatives, removal of the $3-\mathrm{CF}_{3}$ group in the lipophilic section caused decreased activity in the shorter analogue $28(7.50 \mu \mathrm{M})$. Interestingly, removal of the 4-halogen in this lipophilic section did not affect the $\mathrm{IC}_{50}$ value of compounds 29 and 30 compared to their analogue 3 . This could be explained by the compensation of bulky and lipophilic effects when going from trifluoromethyl $\left(-\mathrm{CF}_{3}\right)$ to bulkier pentafluorosulfanyl $\left(-\mathrm{SF}_{5}\right)$ substitution.

The 3,4'-bis-guanidines phenyloxypyridines 49-52, 2 and 4 show, overall, increased HL-60 cytotoxicity than the previously discussed derivatives. Compound $\mathbf{2}$, the pyridine analogue of $\mathbf{1}$, has an $\mathrm{IC}_{50}$ value of $2.36 \mu \mathrm{M}$, a four-fold increased activity compared to $\mathbf{1}$. Likewise, compound 52 with a 3- $\mathrm{CF}_{3}-4-\mathrm{Br}$ phenyl system, shows a low $\mathrm{IC}_{50}$ of $1.53 \mu \mathrm{M}$. Surprisingly, the introduction of a pyridinoguanidinium system as in compound $49(11.61 \mu \mathrm{M})$ instead of a phenylguanidinium moiety as in $3(>100 \mu \mathrm{M})$ results in increased HL-60 cytotoxicity. Even though this is not the most active compound of the series, it is a clear indication of the importance of the pyridinoguanidinium system in improving cytotoxicity in HL-60 cells.

Interestingly, compound 4, which includes both a shorter - $\mathrm{NH}$ - link and the pyridinoguanidinium moiety has a relatively low $\mathrm{IC}_{50}$ value of $3.48 \mu \mathrm{M}$. Compound 70, with a $-\mathrm{NH}$ - link and an isouronium instead of the para guanidinium, shows similar cell viability as the guanidinium analogue 3 . From these results we can deduce that the isouronium cation has a similar behaviour to the guanidinium cation, as we had previously observed in the $3,4^{\prime}$-bis-guanidinium series [20]. Finally, compound 75, where the 
para guanidinium is replaced by a sulfamide, shows a decreased cytotoxicity in HL-60 cells to $9.14 \mu \mathrm{M}$, indicating the importance of the guanidinium or isouronium cations.

The $\mathrm{IC}_{50}$ values obtained for selected compounds in the MCF-7 cell line (Table 2, Figure S8) were similar to the results obtained for the HL-60 cell line with most values in the low $\mu \mathrm{M}$ range. Compounds 3 and $4\left(\mathrm{IC}_{50}=2.02\right.$ and $3.73 \mu \mathrm{M}$, respectively) are still the most cytotoxic agents compared to compound 1 ( $\mathrm{IC}_{50}$ of $\left.9.30 \mu \mathrm{M}\right)$. The pyridine ring present in compounds 4 and 2 still appears responsible for the improved activity, even though less accentuated than in the HL-60 cell line. Instead, the isouronium version of compound 3, compound 70, has an increased $\mathrm{IC}_{50}$ in MCF-7 cells compared with HL-60 cells indicating a certain degree of cell selectivity.

We have also evaluated the effect of compounds $2,3,4$, and 1 on the viability of the HeLa cell line and the results are reported in Table 2 (Figure S9). In this cell line, compound 4 showed again the lowest $\mathrm{IC}_{50}$ value $(1.33 \mu \mathrm{M})$. The rest of the compounds maintained similar cytotoxic activity in HeLa cells compared to HL-60 and MCF-7 cells.

It is known that sorafenib was originally developed as an inhibitor of the Ras effector RAF, and there are studies showing that sorafenib enhances the therapeutic efficacy of rapamycin in certain colorectal cancers [33]. The $\mathrm{IC}_{50}$ results in Table 2 (Figure S10) show that compound $\mathbf{1}$ has more potency in the HCT116 KRAS mutated cancer cell line $(9.96 \mu \mathrm{M})$ than in the HKH-2 KRAS wt isogenic form $(19.18 \mu \mathrm{M})$. Remarkably, its cytotoxic effect is like that of sorafenib in HCT116 $(6.79 \mu \mathrm{M})$, but not in $\mathrm{HKH}-2$, where sorafenib has a much lower $\mathrm{IC}_{50}$. Similar activity in both cell lines is reached with compound 2, while 4 is revealed to be the most active of the series with an $\mathrm{IC}_{50}$ of $4.59 \mu \mathrm{M}$ in HCT116 and 2.88 $\mu \mathrm{M}$ in $\mathrm{HKH}-2$. Interestingly, compound 3, which has a phenyl group instead of the 2-pyridinyl of compounds $\mathbf{2}$ and $\mathbf{4}$, shows poor cytotoxic activity in both cell lines.

Searching for a relationship between physicochemical properties and cytotoxicity, we observed a trend between the calculated $\log \mathrm{P}$ and the HL-60 IC $\mathrm{I}_{50}$ values obtained for all synthesised compounds (except the inactive 5 and 6, $\mathrm{IC}_{50}>100 \mu \mathrm{M}$ ) (Figure S11). This supports our hypothesis that the hydrophobic moiety of our molecules interacts with a specific allosteric hydrophobic pocket in protein kinases, justifying the use of bulkier and more lipophilic substituents (larger $\log \mathrm{P}$ ) in order to obtain improved anti-cancer activity (lower $\mathrm{IC}_{50}$ values).

Therefore, some structure-activity relationships (SARs) can be drawn from the cell viability assays (Figure 4): (i) the hydrophobic moiety is necessary for the activity; particularly, bulky and lipophilic substituents improve the cytotoxicity of these compounds (I- or Br-substitution at the 4-position better than $\mathrm{Cl}-$ ), and a substituent at the 3-position is required to maintain efficacy $\left(\mathrm{CF}_{3}\right.$ or $\left.\mathrm{SF}_{5}\right)$; (ii) replacement of the di-substituted guanidinium in compound $\mathbf{1}$ (position 3 of the phenyloxyaryl core) by a shorter -NH- link results in compounds with better cytotoxicity; (iii) a mono-substituted guanidinium group as in compound $\mathbf{1}$ (position $4^{\prime}$ of the phenyloxyaryl core) gives the greatest cytotoxic activity; additionally, incorporating a 2-pyridinyl instead of a phenyl group, attached to this guanidinium facilitates forming an IMHB that seems to affect positively the cytotoxic activity.

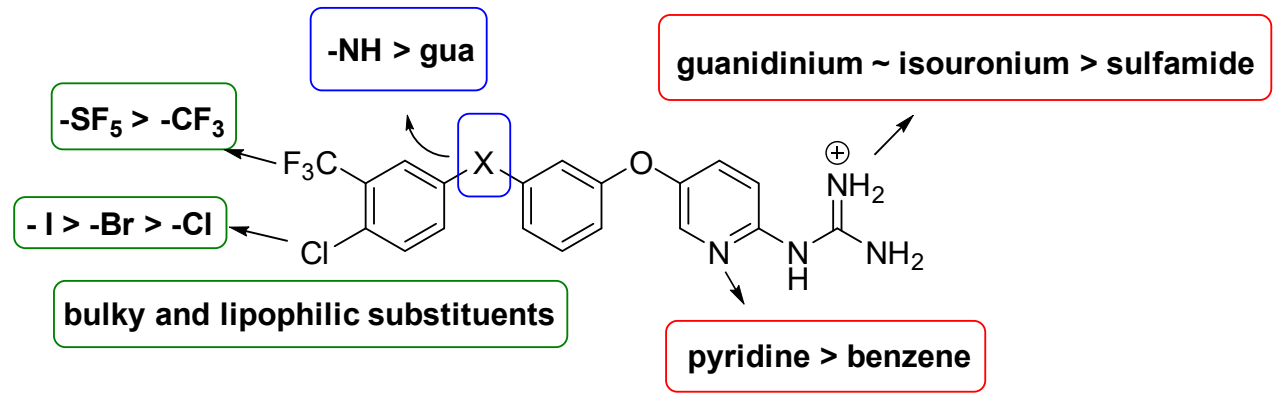

Figure 4. Structure Activity Relationship (SAR) deduced from the analysis of the HL-60 cytotoxicity results.

Considering the promising cytotoxicity results obtained with the cancer cell lines, we also evaluated the potential toxicity of the most efficient derivative (compound 4) in the non-cancerous cell 
line MCF10A (human mammary epithelial cell line). We observed that this compound 4 only shows toxicity towards MCF10A at a high concentration of $100 \mu \mathrm{M}$ while at lower concentrations of 10 and $1 \mu \mathrm{M}$ the compound does not appear to affect in any way cell viability (Figure S12).

\subsubsection{Apoptosis Assay in HL-60}

We have previously reported that compound 1 induces $68.9 \pm 0.1 \%$ apoptosis in HL-60 cells at a

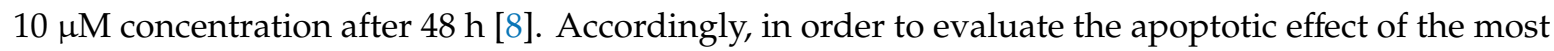
relevant derivatives $(2,3$, and 4 ), HL-60 cells were treated with these compounds (at $5 \mu \mathrm{M}, 5 \mu \mathrm{M}$, and $4 \mu \mathrm{M}$ concentration, respectively) for $48 \mathrm{~h}$, stained with annexin V-FITC/PI and analysed using flow cytometry (Figure 5).

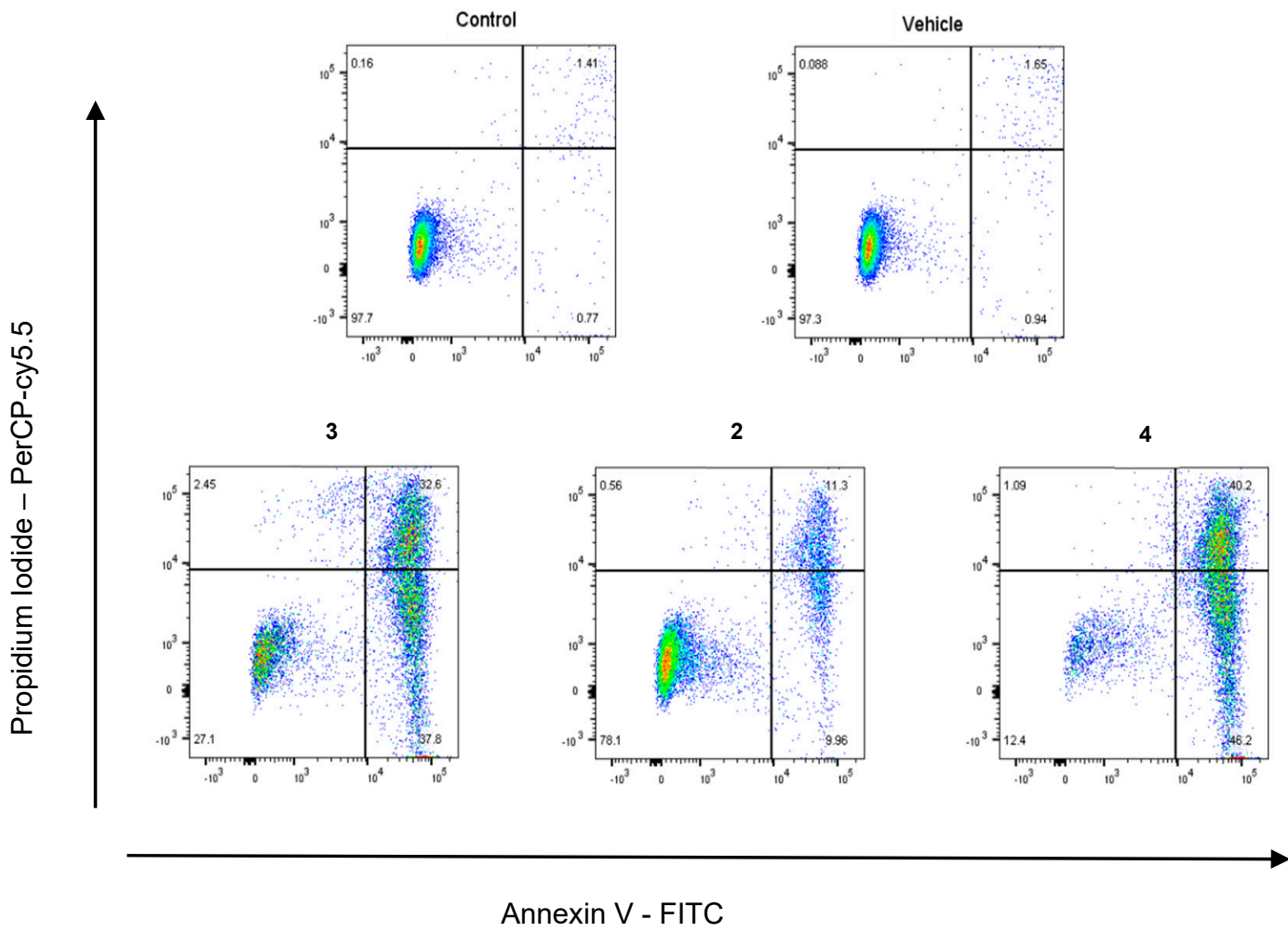

Figure 5. Annexin V-FITC vs. PI flow cytometry analysis of HL-60 cancer cells treated with compounds $3(5 \mu \mathrm{M}), 2(5 \mu \mathrm{M})$ and $4(4 \mu \mathrm{M})$ for $48 \mathrm{~h}$. These figures are representative of three independent experiments. The viable cells, early apoptotic, necrotic and late apoptotic cells are represented by the lower left, lower right, upper left and upper right quadrants, respectively.

The results presented in Figure 5 and Figure S13 show that, under these conditions, a more potent induction of apoptosis was observed with $3(82.5 \pm 11.3 \%)$ and $4(92.7 \pm 5.5 \%)$ compared to compound 2 $(30.7 \pm 11.6 \%)$. As the alamarBlue assay indirectly assesses cytotoxicity by quantifying cell viability and proliferation, these data suggest that compound $\mathbf{2}$ may have a predominantly cytostatic mechanism of action.

\subsubsection{Effect on the MAPK/ERK Pathway}

Taking into account the positive binding results obtained in the docking studies to the BRAF-ATP model and the promising cytotoxicity shown in several cancer cells, we next explored the effect of compounds with $\mathrm{IC}_{50}$ near to that of sorafenib $(\mathbf{1}, \mathbf{2}, \mathbf{3}, \mathbf{4}, \mathbf{9}$, and 52) on the MAPK/ERK pathway. Thus, using Western immunoblot analysis of HL-60 extracts, we investigated the expression and phosphorylation levels of ERK (as an indication of ERK activation), which is the downstream effector of the Ras/BRAF signalling pathway (Figure 6). 


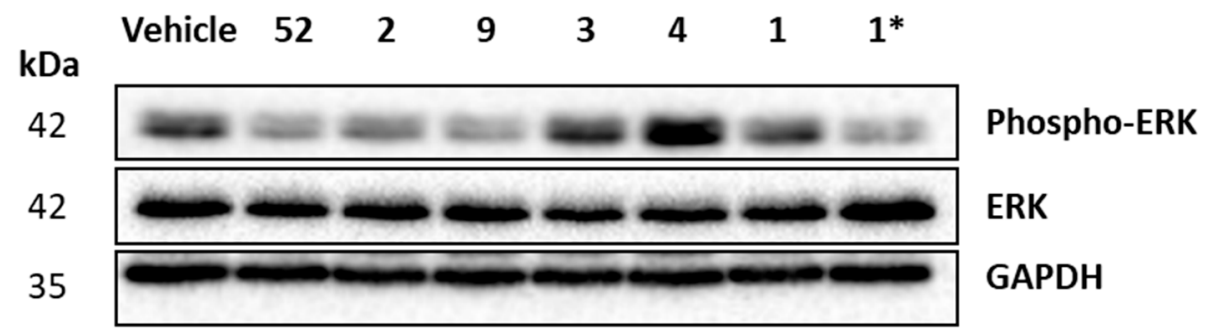

Figure 6. Western immunoblot of HL-60 cell extracts following incubation with compounds 2, 3, 4, 9, 52 and 1 (as a control). HL60 cells were seeded at $2 \times 10^{5}$ cells $/ \mathrm{mL}$ and were treated with either vehicle $[0.5 \% \mathrm{EtOH}(v / v)]$, compounds $52,2,9,3$ and $4(5 \mu \mathrm{M})$ or compound 1 (5 and $\left({ }^{*}\right) 10 \mu \mathrm{M}$, as in reference [9]) for $16 \mathrm{~h}$. Cells were lysed and equal amounts of protein were loaded and separated on $15 \%$ SDS-PAGE gels, transferred to PVDF membrane and probed with antibodies against total and phosphorylated ERK. Anti-GAPDH was used as a loading control. Results are representative of 2 independent experiments.

We observed that compounds 3 and 4 do not appear to interfere with the Ras/BRAF signalling pathway; however, compounds 2, 9, and $\mathbf{5 2}$ have a similar effect as lead compound $\mathbf{1}$ (both at 5 and $10 \mu \mathrm{M})$ in inhibiting ERK phosphorylation and therefore inhibiting the Ras/BRAF pathway. These results may suggest that the potent cytotoxicity observed with these derivatives may be due to different mechanisms of action. Therefore, compounds 2, 9, and 52, which are all 3,4'-bis-guanidino phenyloxy(phenyl or pyridyl) analogues of 1 with similar lipophilic moieties $\left(3-\mathrm{CF}_{3}, 4-(\mathrm{Br} / \mathrm{Cl})-\mathrm{Ph}\right)$, may exert their cytotoxicity by interfering with the Ras/BRAF pathway. On the contrary, compounds 3 and 4 (shorter 3-amino-4'-guanidino phenyloxy(phenyl or pyridyl) derivatives) may act in a different signalling pathway or in the same pathway but through a different mechanism from compound 1 [6]. Pulikakos and co-workers have reported that the biochemical effect of a RAF inhibitor on ERK signalling would be the combined outcome of different mechanisms [34], clearly indicating the complexity of the biological target and opening the door to future studies to understand the mechanism of action of these compounds.

\section{Discussion}

Considering the promising results previously obtained for lead compound $\mathbf{1}$ we explored several modifications to improve its cytotoxicity in different cancer cell lines. Accordingly, we designed a variety of compounds where different changes have been introduced: several lipophilic groups were considered; the di-substituted guanidine was replaced by a secondary amine; the phenyl ring was exchanged with a pyridine; and the mono-substituted guanidine in the polar side was switched to an isourea or a sulfanylamide group.

Molecular docking was utilised to understand the interactions between the proposed biological target and model compounds $\mathbf{1}-\mathbf{4}$. Thus, considering the putative activity of $\mathbf{1}$ as a type-III kinase inhibitor, compounds 1-4 were docked into an in-house model of an active TP-containing BRAF kinase. All final poses exhibit similar interactions between the lipophilic moiety and the lipophilic pocket, as well as between the mono-substituted guanidinium and one of the phosphate groups of TP.

Based on this computational study, 3,4'-bis-guanidino diphenyl ether derivatives 5-11 were prepared by reacting the corresponding 3,4'-diamino diphenyl ether with conveniently substituted Boc-protected thioureas. Additionally, synthesis of the 3-amino-4'-guanidino diphenyl ethers 3, 28-30 and 36 required the preparation of the corresponding starting diamines. Furthermore, preparation of 3,4'-bis-guanidino and 3-amino-4'-guanidino phenylpyridyl ether derivatives $\mathbf{2}, \mathbf{4 9 - 5 2}$, and 4, required different synthetic approaches involving Buchwald-Hartwig coupling. Finally, the 3-amino-4'isouronium 70 and 3 -amino- $4^{\prime}$-sulfonamido 75 derivatives were prepared following specific synthetic routes. All compounds were obtained as hydrochloride salts and their purity was determined to be $>95 \%$ by HPLC before proceeding to biological testing. 
A screening of the cytotoxicity of all compounds was performed in the HL-60 cell line and the more potent compounds were selected for further biological evaluation in MCF-7, HeLa, HCT116, and $\mathrm{HKH}-2$ cell lines. These cell viability studies revealed that these compounds can inhibit cell proliferation in the low $\mu \mathrm{M}$ range, showing up to a nine-fold increase in cytotoxicity compared to lead compound 1. All modifications explored generated SAR information which helped to understand the structural requirements for a more potent cytotoxicity. Cytotoxicity of compound 4 was also evaluated against non-tumorigenic MCF10A and the results show that, at active concentration in cancer cell lines, compound 4 has no toxic effects to non-tumorigenic cells.

Flow cytometry in HL-60 cell lines was also performed to assess the apoptotic effect of compounds 2,3 , and 4 . The results are in agreement with the corresponding structures; thus, mono-guanidinium compounds (3 and 4) induce a stronger apoptotic effect in HL-60 cells (82\% and 92\%, respectively) compared to the bis-guanidinium compounds (1 and 2, around $60 \%{ }^{7}$ and $30 \%$, respectively).

With the aim of determining whether compounds 1-4, 9, and 52 exert their anticancer activity by interfering with the Ras/BRAF pathway (as previously suggested by us for lead compound 1), Western immunoblot analysis was performed with HL-60 cell extracts measuring the activation of the downstream effector ERK. Thus, we observed that compounds 1, 2, 9, and 52 (3,4'-bis-guanidine phenyloxy(phenyl or pyridyl) derivatives) abrogates ERK activation, suggesting potential inhibition of the Ras/BRAF pathway; however, compounds 3 and 4 (shorter derivatives) do not act in the same way.

\section{Materials and Methods}

\subsection{Computational Details}

\subsubsection{Ligand Optimization}

All ligands were fully optimized at DFT level using the M06-2X functional with the 6-311+G* basis set as implemented in the Gaussian16 package [35]. Frequency calculations were performed at the same computational level to confirm that the resulting optimized structures were energetic minima. The effect of water solvation was accounted for by using the SCRF-PCM approach implemented in the Gaussian16 package including dispersion, repulsion and cavitation energy terms of the solvent in the optimization.

\subsubsection{Docking Experiments}

The program AutoDock Vina 4.2 was used to carry out docking studies [36]. The ligands were flexibly docked into the rigid in-house TP-containing BRAF model (see details in ESI). The corresponding docking scores (G-scores) were measured in $\mathrm{kcal} / \mathrm{mol}$ and are only indicative of the quality of the interaction with the target; they do not provide a quantitative measure of binding. Poses obtained from the docking were visualised with VMD [37].

\subsection{Chemistry}

\subsubsection{1-(4-Fluorophenyl)-2-(3-(4-guanidinophenoxy)phenyl)guanidine dihydrochloride (5)}

Following Method A (see ESI), 21 (80 mg, $0.12 \mathrm{mmol}$ ) was dissolved in $4 \mathrm{M} \mathrm{HCl}$ in dioxane $(0.54 \mathrm{~mL}, 2.16 \mathrm{mmol})$ and in additional dioxane $(0.07 \mathrm{~mL})$ until a final concentration of $0.2 \mathrm{M}$ was reached. After $8 \mathrm{~h}$ stirring at $55^{\circ} \mathrm{C}$, the reaction was adjudged complete (TLC), solvents were evaporated and the residue was purified by silica gel $\left(\mathrm{CH}_{3} \mathrm{Cl}: \mathrm{MeOH}\right)$ chromatography to afford the pure hydrochloride salt as a white-yellow solid (35 mg, $76 \%)$. Mp: decomp. $>180{ }^{\circ} \mathrm{C}$. $\delta_{\mathrm{H}}(400 \mathrm{MHz}$, $\left.\mathrm{CD}_{3} \mathrm{OD}\right): 7.00(\mathrm{dd}, J=8.3,2.4,1 \mathrm{H}, \mathrm{H}-4), 7.04(\mathrm{t}, J=2.1 \mathrm{~Hz}, 1 \mathrm{H}, \mathrm{H}-2), 7.13-7.17(\mathrm{~m}, 3 \mathrm{H}, \mathrm{H}-8$ and $\mathrm{H}-8^{\prime}$ and H-6), 7.19-7.24 (m, 2H, H-13 and H-13'), $7.31\left(\mathrm{~d}, J=8.9 \mathrm{~Hz}, 2 \mathrm{H}, \mathrm{H}-9\right.$ and $\left.\mathrm{H}-9^{\prime}\right), 7.36-7.39$ $\left(\mathrm{m}, 2 \mathrm{H}, \mathrm{H}-12\right.$ and $\left.\mathrm{H}-12^{\prime}\right), 7.47(\mathrm{t}, J=8.1 \mathrm{~Hz}, 1 \mathrm{H}, \mathrm{H}-5) . \delta_{\mathrm{C}}\left(100 \mathrm{MHz}, \mathrm{CD}_{3} \mathrm{OD}\right): 116.5(\mathrm{CH} \mathrm{Ar}, \mathrm{C}-2)$, $117.8(\mathrm{~d}, J=23.3 \mathrm{~Hz}, 2 \mathrm{CH}$ Ar, C-13 and C-13'), 118.6 (CH Ar, C-4), 121.1 (CH Ar, C-6), 121.5 (2 CH Ar, C-8 and C-8' $), 129.95(\mathrm{~d}, J=8.8 \mathrm{~Hz}, 2 \mathrm{CH}$ Ar, C-12 and C-12' $), 128.96$ (2 CH Ar, C-9 and C-9' $), 131.6$ (qC), 
$132.3(\mathrm{~d}, J=3.1 \mathrm{~Hz}, \mathrm{qC}, \mathrm{C}-11), 132.4(\mathrm{CH} \mathrm{Ar}, \mathrm{C}-5), 138.0(\mathrm{qC}), 156.6$ (qC), $157.4(\mathrm{qC}), 158.4(\mathrm{qC}), 159.5(\mathrm{qC})$, $163.2(\mathrm{~d}, J=246.1 \mathrm{~Hz}, \mathrm{qC}, \mathrm{C}-14) . \delta_{\mathrm{F}}\left(376 \mathrm{MHz}, \mathrm{CD}_{3} \mathrm{OD}\right):-115.93(\mathrm{~m}) . v_{\max }(\mathrm{ATR}) / \mathrm{cm}^{-1}: 3110(\mathrm{NH})$, $3052(\mathrm{NH}), 2922$, 2330, 2134, $1655(\mathrm{C}=\mathrm{N}), 1582(\mathrm{C}=\mathrm{N}), 1505(\mathrm{C}-\mathrm{N}), 1486,1404,1212(\mathrm{C}-\mathrm{O}), 1066$ (C-F), 834, 792, 552. HRMS $\left(\mathrm{m} / \mathrm{z} \mathrm{ESI}^{+}\right)$: found: $379.1687\left(\mathrm{M}^{+}+\mathrm{H}\right), \mathrm{C}_{20} \mathrm{H}_{20} \mathrm{~N}_{6} \mathrm{OF}$ requires: 379.1683. HPLC: $99.7 \%$ ( $t R: 22.9 \mathrm{~min})$.

\subsubsection{1-(3:4-Di-fluorophenyl)-2-(3-(4-guanidinophenoxy)phenyl)guanidine dihydrochloride (6)}

Following Method A (see ESI), 22 ( $53 \mathrm{mg}, 0.08 \mathrm{mmol}$ ) was dissolved in $4 \mathrm{M} \mathrm{HCl}$ in dioxane $(0.36 \mathrm{~mL}$, $1.37 \mathrm{mmol})$ and in additional dioxane $(0.06 \mathrm{~mL})$ until a final concentration of $0.2 \mathrm{M}$ was reached. After $8 \mathrm{~h}$ stirring at $55^{\circ} \mathrm{C}$, the reaction was adjudged complete (TLC), solvents were evaporated and the residue was purified by silica gel chromatography $\left(\mathrm{CHCl}_{3}: \mathrm{MeOH}\right)$ to afford the pure hydrochloride salt as a white solid $(34 \mathrm{mg}, 90 \%)$. Mp: $158-160{ }^{\circ} \mathrm{C} . \delta_{\mathrm{H}}\left(400 \mathrm{MHz}, \mathrm{CD}_{3} \mathrm{OD}\right): 7.00(\mathrm{dd}, J=8.3,2.4 \mathrm{~Hz}, 1 \mathrm{H}$, $\mathrm{H}-4), 7.05(\mathrm{t}, J=2.2 \mathrm{~Hz}, 1 \mathrm{H}, \mathrm{H}-2), 7.13-7.20\left(\mathrm{~m}, 4 \mathrm{H}, \mathrm{H}-8\right.$ and H-8 ${ }^{\prime}, \mathrm{H}-6$ and $\left.\mathrm{H}-16\right), 7.32(\mathrm{~d}, J=8.9 \mathrm{~Hz}, 2 \mathrm{H}$, H-9 and H-9'), 7.34-7.41 (m, 2H, H-12 and H-15), $7.47(\mathrm{t}, J=8.1 \mathrm{~Hz}, 1 \mathrm{H}, \mathrm{H}-5)$. $\delta_{\mathrm{C}}\left(100 \mathrm{MHz}, \mathrm{CD}_{3} \mathrm{OD}\right)$ : $116.3(\mathrm{~d}, J=19.7 \mathrm{~Hz}, \mathrm{C}-12$ or C-15), $116.5(\mathrm{CH}$ Ar, C-2), $118.6(\mathrm{CH} \mathrm{Ar}, \mathrm{C}-4), 119.5(\mathrm{~d}, J=18.8 \mathrm{~Hz}$, C-12 or C-15), 121.1 (CH Ar, C-6), 121.5 (2 CH Ar, C-8 and C-8'), 123.4 (dd, J = 6.7, 3.7 Hz, C-16), 129.0 (2 CH Ar, C-9 and C-9'), 131.6 (qC), $132.4(\mathrm{CH} \mathrm{Ar}, \mathrm{C}-5), 133.0$ (dd, J = 8.3, 3.6 Hz, qC, C-11), $137.9(\mathrm{qC}), 150.8(\mathrm{dd}, J=247.8,12.6 \mathrm{~Hz}, \mathrm{qC}, \mathrm{C}-13$ or C-14), $151.8(\mathrm{dd}, J=248.7,13.7 \mathrm{~Hz}, \mathrm{qC}, \mathrm{C}-13$ or C-14), $156.5(\mathrm{qC}), 157.4(\mathrm{qC}), 158.3(\mathrm{qC}), 159.5(\mathrm{qC}) . \delta_{\mathrm{F}}\left(376 \mathrm{MHz}, \mathrm{CD}_{3} \mathrm{OD}\right):-137.23(\mathrm{~m}),-141.12(\mathrm{~m})$. $v_{\max }(\mathrm{ATR}) / \mathrm{cm}^{-1}: 3228(\mathrm{NH}), 3040(\mathrm{NH}), 2923,2853,1655(\mathrm{C}=\mathrm{N}), 1579(\mathrm{C}=\mathrm{N}), 1505,1485,1401,1259$, 1211 (C-F), 1149, 972, 825, 771, 694, 649, 609, 587. HRMS (m/z ESI $\left.{ }^{+}\right)$: found: $397.1598\left(\mathrm{M}^{+}+\mathrm{H}\right)$, $\mathrm{C}_{20} \mathrm{H}_{19} \mathrm{~N}_{6} \mathrm{OF}_{2}$ requires: 397.1588. HPLC: $96.8 \%$ ( $\left.t \mathrm{R}: 23.2 \mathrm{~min}\right)$.

\subsubsection{1-(2-Fluoro-4-iodophenyl)-2-(3-(4-guanidinophenoxy)phenyl)guanidine dihydrochloride (7)}

Following Method A (see ESI), 23 (357 mg, $0.44 \mathrm{mmol}$ ) was dissolved in $4 \mathrm{M} \mathrm{HCl}$ in dioxane $(2 \mathrm{~mL}, 7.92 \mathrm{mmol})$ and in additional dioxane $(0.2 \mathrm{~mL})$ until a final concentration of $0.2 \mathrm{M}$ was reached. After $8 \mathrm{~h}$ stirring at $55^{\circ} \mathrm{C}$, the reaction was adjudged complete (TLC), solvents were evaporated and the residue was purified by silica gel chromatography $\left(\mathrm{CH}_{3} \mathrm{Cl}: \mathrm{MeOH}\right)$ to afford the pure hydrochloride salt as a white solid $(210 \mathrm{mg}, 83 \%)$. Mp: decomp. $>180^{\circ} \mathrm{C}$. $\delta_{\mathrm{H}}\left(400 \mathrm{MHz}, \mathrm{CD}_{3} \mathrm{OD}\right): 6.99-7.01(\mathrm{~m}, 2 \mathrm{H}$, H-2 and H-4), 7.11-7.14 (m, 1H, H-6), $7.15(\mathrm{~d}, J=8.9 \mathrm{~Hz}, 2 \mathrm{H}, \mathrm{H}-8$ and H-8'), $7.20(\mathrm{t}, J=8.2 \mathrm{~Hz}$, $1 \mathrm{H}, \mathrm{H}-5), 7.33\left(\mathrm{~d}, J=8.9 \mathrm{~Hz}, 2 \mathrm{H}, \mathrm{H}-9\right.$ and $\left.\mathrm{H}-9^{\prime}\right), 7.44-7.49(\mathrm{~m}, 1 \mathrm{H}, \mathrm{H}-15), 7.64-7.66(\mathrm{~m}, 1 \mathrm{H}, \mathrm{H}-16)$, $7.69(\mathrm{dd}, J=9.6,1.8 \mathrm{~Hz}, 1 \mathrm{H}, \mathrm{H}-13) . \delta_{\mathrm{C}}\left(100 \mathrm{MHz}, \mathrm{CD}_{3} \mathrm{OD}\right): 93.4(\mathrm{~d}, J=7.5 \mathrm{~Hz}, \mathrm{qC}, \mathrm{C}-14), 116.4(\mathrm{CH} \mathrm{Ar}$, C-2), 118.6 (CH Ar, C-4), $121.0(\mathrm{CH} \mathrm{Ar}, \mathrm{C}-6), 121.5$ (2 CH Ar, C-8 and C-8'), 124.1 (d, J = 12.4 Hz, qC, C-11), 127.3 (d, J = 22.2 Hz, CH Ar, C-13), 128.9 (2 CH Ar, C-9 and C-9'), 130.9 (CH Ar, C-5), 131.5 (qC), 132.4 (CH Ar, C-15), 136.0 (d, J = 3.9 Hz, CH Ar, C-16), 137.9 (qC), 156.4 (qC), 158.0 (d, J = 254.4 Hz, qC, C-12), $157.3(\mathrm{qC}), 158.3(\mathrm{qC}), 159.5(\mathrm{qC}) . \delta_{\mathrm{F}}\left(376, \mathrm{CD}_{3} \mathrm{OD}\right):-121.10(\mathrm{t}, J=8.9 \mathrm{~Hz}) . v_{\max }(\mathrm{ATR}) / \mathrm{cm}^{-1}$ : $3318(\mathrm{NH}), 3098(\mathrm{NH}), 2958,1661(\mathrm{C}=\mathrm{N})$, 1620, 1579, 1485, $1214(\mathrm{C}-\mathrm{F}), 1149$, 625, 609, 576 (C-I), 566. HRMS $\left(m / z \mathrm{ESI}^{+}\right)$: found $505.0646\left(\mathrm{M}^{+}+\mathrm{H}\right), \mathrm{C}_{20} \mathrm{H}_{19} \mathrm{~N}_{6} \mathrm{OFI}$ requires: 505.0649 . HPLC: $99.2 \%(t \mathrm{R}$ : $25.3 \mathrm{~min})$.

\subsubsection{1-(4-Bromophenyl)-2-(3-(4-guanidinophenoxy)phenyl)guanidine dihydrochloride (8)}

Following Method A (see ESI), $24(212 \mathrm{mg}, 0.29 \mathrm{mmol})$ was dissolved in $4 \mathrm{M} \mathrm{HCl}$ in dioxane $(1.30 \mathrm{~mL}, 5.22 \mathrm{mmol})$ and in additional dioxane $(0.12 \mathrm{~mL})$ until a final concentration of $0.2 \mathrm{M}$ was reached. After $8 \mathrm{~h}$ stirring at $55^{\circ} \mathrm{C}$, the reaction was adjudged complete (TLC), solvents were evaporated and the residue was purified by flash chromatography to afford the pure hydrochloride salt as a light-yellow solid (128 mg, 87\%). Mp: decomp. $>110^{\circ} \mathrm{C} . \delta_{\mathrm{H}}\left(400 \mathrm{MHz}, \mathrm{CD}_{3} \mathrm{OD}\right): 6.99(\mathrm{dd}, J=8.2,2.3 \mathrm{~Hz}, 1 \mathrm{H}$, $\mathrm{H}-4), 7.03(\mathrm{t}, J=2.2 \mathrm{~Hz}, 1 \mathrm{H}, \mathrm{H}-2), 7.12-7.16\left(\mathrm{~m}, 3 \mathrm{H}, \mathrm{H}-6\right.$ and $\mathrm{H}-8$ and $\left.\mathrm{H}-8^{\prime}\right), 7.27(\mathrm{~d}, J=8.7 \mathrm{~Hz}, 2 \mathrm{H}$, $\mathrm{H}-12$ and $\mathrm{H}-12^{\prime}$ or $\mathrm{H}-13$ and $\left.\mathrm{H}-13^{\prime}\right), 7.31\left(\mathrm{~d}, J=8.8 \mathrm{~Hz}, 2 \mathrm{H}, \mathrm{H}-9\right.$ and $\left.\mathrm{H}-9^{\prime}\right), 7.46(\mathrm{t}, J=8.1 \mathrm{~Hz}, 1 \mathrm{H}, \mathrm{H}-5)$, $7.61\left(\mathrm{~d}, J=8.7 \mathrm{~Hz}, 2 \mathrm{H}, \mathrm{H}-12\right.$ and H-12' or $\mathrm{H}-13$ and H-13'). $\delta_{\mathrm{C}}\left(100 \mathrm{MHz}, \mathrm{CD}_{3} \mathrm{OD}\right): 116.3(\mathrm{CH} \mathrm{Ar}, \mathrm{C}-2)$, 118.5 (CH Ar, C-4), 120.9 (CH Ar, C-6), 121.5 (2 CH Ar, C-8 and C-8'), 121.7 (qC, C-14), 127.9 (2 CH Ar, 
C-12 and C-12' or C-13 and C-13'), 128.9 (2 CH Ar, C-9 and C-9'), 131.5 (qC), 132.4 (CH Ar, C-5), 134.1 (CH Ar, C-12 and C-12' or C-13 and C-13'), $135.8(\mathrm{qC}), 138.0(\mathrm{qC}), 156.2(\mathrm{qC}), 157.4(\mathrm{qC}), 158.3(\mathrm{qC})$, $159.5(\mathrm{qC}) . v_{\max }(\mathrm{ATR}) / \mathrm{cm}^{-1}$ : $3124(\mathrm{NH}), 3044(\mathrm{NH}), 1655,1571(\mathrm{C}=\mathrm{N}), 1504(\mathrm{C}=\mathrm{N})$, 1484, 1405, 1213 (C-O), 1070 (C-Br), 1010, 617-567. HRMS (m/z APCI ${ }^{+}$): found: $439.0857\left(\mathrm{M}^{+}+\mathrm{H}\right), \mathrm{C}_{20} \mathrm{H}_{20} \mathrm{BrN}_{6} \mathrm{O}$ requires: 439.0876 . HPLC: $99.8 \%$ ( $t \mathrm{R}: 24.8 \mathrm{~min})$.

4.2.5. 1-(4-Bromo-3-(trifluoromethyl)phenyl)-2-(3-(4-guanidinophenoxy)phenyl)guanidine dihydrochloride (9)

Following Method A (see ESI), 25 (566 mg, $0.70 \mathrm{mmol}$ ) was dissolved in $4 \mathrm{M} \mathrm{HCl}$ in dioxane $(3.15 \mathrm{~mL}, 12.6 \mathrm{mmol})$ and in additional dioxane $(0.35 \mathrm{~mL})$ until a final concentration of $0.2 \mathrm{M}$ was reached. After $8 \mathrm{~h}$ stirring at $55^{\circ} \mathrm{C}$, the reaction was adjudged complete (TLC), solvents were evaporated and the residue was purified by silica gel chromatography $\left(\mathrm{CHCl}_{3}: \mathrm{MeOH}\right)$ to afford the pure hydrochloride salt as a white solid $(361 \mathrm{mg}, 89 \%)$. Mp: decomp. $>136{ }^{\circ} \mathrm{C}$. $\delta_{\mathrm{H}}\left(400 \mathrm{MHz}, \mathrm{CD}_{3} \mathrm{OD}\right)$ : $6.99(\mathrm{dd}, J=8.0,1.9 \mathrm{~Hz}, 1 \mathrm{H}, \mathrm{H}-4), 7.06(\mathrm{t}, J=2.1 \mathrm{~Hz}, 1 \mathrm{H}, \mathrm{H}-2), 7.14-7.16(\mathrm{~m}, 3 \mathrm{H}, \mathrm{H}-8$ and H-8' and H-6), $7.32\left(\mathrm{~d}, J=8.9 \mathrm{~Hz}, 2 \mathrm{H}, \mathrm{H}-9\right.$ and $\left.\mathrm{H}-9^{\prime}\right), 7.46(\mathrm{t}, J=8.1 \mathrm{~Hz}, 1 \mathrm{H}, \mathrm{H}-5), 7.51(\mathrm{dd}, J=8.6,2.4 \mathrm{~Hz}$, $1 \mathrm{H}, \mathrm{H}-16), 7.74(\mathrm{~d}, J=2.4 \mathrm{~Hz}, 1 \mathrm{H}, \mathrm{H}-12), 7.88(\mathrm{~d}, J=8.6 \mathrm{~Hz}, 1 \mathrm{H}, \mathrm{H}-15) . \delta_{\mathrm{C}}\left(100 \mathrm{MHz}, \mathrm{CD}_{3} \mathrm{OD}\right)$ : 116.2 (CH Ar, C-2), 118.3 (qC, C-14), 118.5 (CH Ar, C-4), 120.8 (CH Ar, C-6), 121.5 (2 CH Ar, C-8 and C-8'), $123.9\left(\mathrm{~d}, J=260.3 \mathrm{~Hz}, \mathrm{qCF}_{3}\right), 125.3(\mathrm{~m}, \mathrm{CH} \mathrm{Ar}, \mathrm{C}-12), 128.9(2 \mathrm{CH} \mathrm{Ar}, \mathrm{C}-9$ and C-9'), $130.5(\mathrm{CH} \mathrm{Ar}$, C-16), $131.6(\mathrm{qC}), 132.3(\mathrm{~d}, J=31.7 \mathrm{~Hz}, \mathrm{qC}, \mathrm{C}-13), 132.4(\mathrm{CH} \mathrm{Ar}, \mathrm{C}-5), 136.9(\mathrm{qC}), 137.8(\mathrm{CH} \mathrm{Ar}$, C-15), $138.0(\mathrm{qC}), 156.1(\mathrm{qC}), 157.3(\mathrm{qC}), 158.3(\mathrm{qC}), 159.6(\mathrm{qC}) . \delta_{\mathrm{F}}\left(376 \mathrm{MHz}, \mathrm{CD}_{3} \mathrm{OD}\right):-64.73(\mathrm{~s})$. $v_{\max }($ ATR $) / \mathrm{cm}^{-1}: 3119(\mathrm{NH}), 3053(\mathrm{NH}), 1663(\mathrm{C}=\mathrm{O}), 1584(\mathrm{C}=\mathrm{N}), 1478,1412,1320(\mathrm{C}-\mathrm{F}), 1238,1214$, 1174, $1129\left(\mathrm{CF}_{3}\right), 1099(\mathrm{C}-\mathrm{Br}), 1023,828,581-558$. HRMS $\left(\mathrm{m} / \mathrm{z} \mathrm{ESI}^{+}\right)$: found $507.0766\left(\mathrm{M}^{+}+\mathrm{H}\right)$, $\mathrm{C}_{21} \mathrm{H}_{19} \mathrm{~N}_{6} \mathrm{OF}_{3} \mathrm{Br}$ requires: 507.0756. HPLC: 99.9\% ( $\left.t \mathrm{R}: 26.3 \mathrm{~min}\right)$.

\subsubsection{1-(2-Fluoro-4-iodophenyl)-2-(4-(3-guanidinophenoxy)phenyl)guanidine dihydrochloride (10)}

Following Method A (see ESI), 26 (310 mg, $0.39 \mathrm{mmol})$ was dissolved in $4 \mathrm{M} \mathrm{HCl}$ in dioxane $(1.73 \mathrm{~mL}, 6.93 \mathrm{mmol})$ and in additional dioxane $(0.17 \mathrm{~mL})$ until a final concentration of $0.2 \mathrm{M}$ was reached. After $8 \mathrm{~h}$ stirring at $55^{\circ} \mathrm{C}$, the reaction was adjudged complete (TLC), solvents were evaporated and the residue was purified by flash chromatography to afford the pure hydrochloride salt as a white solid $(198 \mathrm{mg}, 88 \%)$. Mp: decomp. $>150{ }^{\circ} \mathrm{C}$. $\delta_{\mathrm{H}}\left(400 \mathrm{MHz}, \mathrm{CD}_{3} \mathrm{OD}\right): 6.97(\mathrm{t}, J=2.1 \mathrm{~Hz}, 1 \mathrm{H}, \mathrm{H}-2)$, $7.00(\mathrm{dd}, J=8.2,2.3 \mathrm{~Hz}, 1 \mathrm{H}, \mathrm{H}-4), 7.08(\mathrm{dd}, J=7.6,1.5 \mathrm{~Hz}, 1 \mathrm{H}, \mathrm{H}-6), 7.16(\mathrm{~d}, J=8.8 \mathrm{~Hz}, 2 \mathrm{H}, \mathrm{H}-8$ and H-8 $\left.{ }^{\prime}\right), 7.22(\mathrm{t}, J=8.2 \mathrm{~Hz}, 1 \mathrm{H}, \mathrm{H}-5$ or H-15), $7.36(\mathrm{~d}, J=8.8 \mathrm{~Hz}, 2 \mathrm{H}, \mathrm{H}-9$ and H-9'), $7.47(\mathrm{t}, J=8.1 \mathrm{~Hz}, 1 \mathrm{H}$, H-5 or H-15), $7.66(\mathrm{~d}, J=9.1 \mathrm{~Hz}, 1 \mathrm{H}, \mathrm{H}-16), 7.70(\mathrm{dd}, J=9.6,1.7 \mathrm{~Hz}, 1 \mathrm{H}, \mathrm{H}-13) . \delta_{\mathrm{C}}\left(100 \mathrm{MHz}, \mathrm{CD}_{3} \mathrm{OD}\right)$ : $93.5(\mathrm{~d}, J=7.5 \mathrm{~Hz}, \mathrm{qC}, \mathrm{C}-14), 116.6(\mathrm{CH} \mathrm{Ar}, \mathrm{C}-2), 118.6$ (CH Ar, C-4), 121.3 (CH Ar, C-6), 121.6 (2 CH Ar, C-8 and C-8'), $124.0(\mathrm{~d}, J=12.5 \mathrm{~Hz}, \mathrm{qC}, \mathrm{C}-11), 127.3(\mathrm{~d}, J=22.2 \mathrm{~Hz}, \mathrm{C}-13), 128.7$ (2 CH Ar, C-9 and C-9'), 131.1 (CH Ar, C-5 or C-15), 131.6 (qC), 132.4 (CH Ar, C-5 or C-15), 136.0 (d, J = 3.9 Hz, C-16), 137.7 (qC), $156.8(\mathrm{qC}), 157.3(\mathrm{qC}), 157.9(\mathrm{qC}), 158.2(\mathrm{~d}, J=254.5 \mathrm{~Hz}, \mathrm{qC}, \mathrm{C}-12), 159.5(\mathrm{qC}) . \delta_{\mathrm{F}}\left(376 \mathrm{MHz}, \mathrm{CD}_{3} \mathrm{OD}\right)$ : $-121.04(\mathrm{t}, J=8.8 \mathrm{~Hz}) . v_{\max }(\mathrm{ATR}) / \mathrm{cm}^{-1}: 3335(\mathrm{NH}), 3265(\mathrm{NH}), 3180(\mathrm{NH}), 3052,2868,2325,1616(\mathrm{C}=\mathrm{N})$, $1560(\mathrm{C}=\mathrm{N}), 1504,1400,1226(\mathrm{C}-\mathrm{F}), 1162,1109,971,875,789,684-573(\mathrm{C}-\mathrm{I})$. HRMS ( $\left.\mathrm{m} / \mathrm{z} \mathrm{ESI}^{+}\right)$: found: 505.0645 $\left(\mathrm{M}^{+}+\mathrm{H}\right), \mathrm{C}_{20} \mathrm{H}_{19} \mathrm{~N}_{6} \mathrm{OFI}$ requires: 505.0649. HPLC: 99.9\% ( $\left.t \mathrm{R}: 25.9 \mathrm{~min}\right)$.

4.2.7. 1-(4-Bromo-3-(trifluoromethyl)phenyl)-2-(4-(3-guanidinophenoxy)phenyl)guanidine dihydrochloride (11)

Following Method A (see ESI), $27(148 \mathrm{mg}, 0.18 \mathrm{mmol}$ ) was dissolved in $4 \mathrm{M} \mathrm{HCl}$ in dioxane $(0.81 \mathrm{~mL}, 3.24 \mathrm{mmol})$ and in additional dioxane $(0.10 \mathrm{~mL})$ until a final concentration of $0.2 \mathrm{M}$ was reached. After $8 \mathrm{~h}$ stirring at $55^{\circ} \mathrm{C}$, the reaction was adjudged complete (TLC), solvents were evaporated and the residue was purified by flash chromatography to afford the pure hydrochloride salt as a white solid (100 mg, 94\%). Mp: decomp. $>95^{\circ} \mathrm{C} . \delta_{\mathrm{H}}\left(400 \mathrm{MHz}, \mathrm{CD}_{3} \mathrm{OD}\right): 6.98-7.02(\mathrm{~m}, 2 \mathrm{H}, \mathrm{H}-2$ and H-4), $7.09(\mathrm{ddd}, 1 \mathrm{H}, J=8.0,1.9,0.9 \mathrm{~Hz}, \mathrm{H}-6), 7.17\left(\mathrm{~d}, J=8.9 \mathrm{~Hz}, 2 \mathrm{H}, \mathrm{H}-8\right.$ and $\left.\mathrm{H}-8^{\prime}\right), 7.41(\mathrm{~d}, J=9.0 \mathrm{~Hz}, 2 \mathrm{H}$, H-9 and H-9'), $7.49(\mathrm{t}, J=8.0 \mathrm{~Hz}, 1 \mathrm{H}, \mathrm{H}-5), 7.55(\mathrm{dd}, J=8.5,2.6 \mathrm{~Hz}, 1 \mathrm{H}, \mathrm{H}-16), 7.77(\mathrm{~d}, J=2.6 \mathrm{~Hz}, 1 \mathrm{H}$, 
$\mathrm{H}-12), 7.91(\mathrm{~d}, J=8.6 \mathrm{~Hz}, 1 \mathrm{H}, \mathrm{H}-15) . \delta_{\mathrm{C}}\left(100 \mathrm{MHz}, \mathrm{CD}_{3} \mathrm{OD}\right): 116.6(\mathrm{CH} \mathrm{Ar}, \mathrm{C}-2$ or C-4), 118.5 (qC, C-14), 118.6 (CH Ar, C-2 or C-4), 121.3 (CH Ar, C-6), 121.6 (2 CH Ar, C-8 and C-8'), 123.9 (d, J = 272.8 Hz, $\left.\mathrm{qCF}_{3}\right), 125.5(\mathrm{q}, J=5.6 \mathrm{~Hz}, \mathrm{CH}$ Ar, C-12), 128.5 (2 CH Ar, C-9 and C-9'), 130.8 (CH Ar, C-16), 131.7 (qC), 132.3 (q, J = 31.6 Hz, qC, C-13), 132.4 (CH Ar, C-5), 136.7 (qC), 137.7 (qC), 137.8 (CH Ar, C-15), 156.5 (qC), $157.3(\mathrm{qC}), 157.9(\mathrm{qC}), 159.6$ (qC). $\delta_{\mathrm{F}}\left(376 \mathrm{MHz}, \mathrm{CD}_{3} \mathrm{OD}\right):-64.30(\mathrm{~s}) . v_{\max }(\mathrm{ATR}) / \mathrm{cm}^{-1}$ : $3309(\mathrm{NH}), 3116(\mathrm{NH}), 3053(\mathrm{NH})$, 2837, 2280, $1663(\mathrm{C}=\mathrm{N}), 1577(\mathrm{C}=\mathrm{N}), 1505,1486$, 1405, 1320, 1258 (C-O), $1214\left(\mathrm{CF}_{3}\right), 1129,1023(\mathrm{C}-\mathrm{Br}), 829,595-575$. HRMS $\left(\mathrm{m} / z \mathrm{ESI}^{+}\right)$: found: $507.0750\left(\mathrm{M}^{+}+\mathrm{H}\right)$, $\mathrm{C}_{21} \mathrm{H}_{19} \mathrm{~N}_{6} \mathrm{OBrF}_{3}$ requires: 507.0756. HPLC: 99.9\% (tR: $\left.26.6 \mathrm{~min}\right)$.

\subsubsection{1-(4-(3-((4-Chlorophenyl)amino)phenoxy)phenyl)guanidine hydrochloride (28)}

Following Method A (see ESI), $44(97 \mathrm{mg}, 0.18 \mathrm{mmol}$ ) was dissolved in $4 \mathrm{M} \mathrm{HCl}$ in dioxane $(0.53 \mathrm{~mL}, 2.10 \mathrm{mmol})$ and in additional dioxane $(0.9 \mathrm{~mL})$ until a final concentration of $0.2 \mathrm{M}$ was reached. After $8 \mathrm{~h}$ stirring at $55^{\circ} \mathrm{C}$, the reaction was adjudged complete (TLC), solvents were evaporated and the residue was purified by silica gel chromatography $\left(\mathrm{CHCl}_{3}: \mathrm{MeOH}\right)$ to afford the pure hydrochloride salt as a purple solid $(69 \mathrm{mg}, 99 \%)$. Mp: $50-52{ }^{\circ} \mathrm{C} . \delta_{\mathrm{H}}\left(400 \mathrm{MHz}, \mathrm{CD}_{3} \mathrm{OD}\right): 6.51(\mathrm{dd}, J=8.3,1.9 \mathrm{~Hz}, 1 \mathrm{H}, \mathrm{H}-4)$, $6.73(\mathrm{t}, J=2.2 \mathrm{~Hz}, 1 \mathrm{H}, \mathrm{H}-2), 6.85(\mathrm{dd}, J=7.8,1.8 \mathrm{~Hz}, 1 \mathrm{H}, \mathrm{H}-6), 7.05(\mathrm{~d}, J=8.9 \mathrm{~Hz}, 2 \mathrm{H}, \mathrm{H}-12$ and H-12'), $7.08\left(\mathrm{~d}, J=8.9 \mathrm{~Hz}, 2 \mathrm{H}, \mathrm{H}-8\right.$ and $\left.\mathrm{H}-8^{\prime}\right), 7.18\left(\mathrm{~d}, J=8.9 \mathrm{~Hz}, 2 \mathrm{H}, \mathrm{H}-13\right.$ and $\left.\mathrm{H}-13^{\prime}\right), 7.22(\mathrm{t}, J=8.2 \mathrm{~Hz}, 1 \mathrm{H}$, H-5), $7.27\left(\mathrm{~d}, J=8.9 \mathrm{~Hz}, 2 \mathrm{H}, \mathrm{H}-9\right.$ and H-9'). $\delta_{\mathrm{C}}\left(100 \mathrm{MHz}, \mathrm{CD}_{3} \mathrm{OD}\right): 108.6(\mathrm{CH} \mathrm{Ar}, \mathrm{C}-2), 111.8$ (CH Ar, C-4), 113.7 ( $\mathrm{CH}$ Ar, C-6), 120.0 (2 CH Ar, C-12 and C-12'), 120.7 (2 CH Ar, C-8 and C-8'), 126.1 (qC, C-14), 128.8 (2 CH Ar, C-9 and C-9'), 130.1 (2 CH Ar, C-13 and C-13'), 130.6 (qC), 131.5 (CH Ar, C-5), $143.4(\mathrm{qC}), 146.7(\mathrm{qC}), 158.4(\mathrm{qC}), 158.5(\mathrm{qC}), 158.9(\mathrm{qC}) \cdot v_{\max }(\mathrm{ATR}) / \mathrm{cm}^{-1}: 3297(\mathrm{~N}-\mathrm{H}), 3126(\mathrm{~N}-\mathrm{H})$, 1688, $1586(\mathrm{C}=\mathrm{N})$, 1502, $1485(\mathrm{C}-\mathrm{N})$, 1325, 1216 (C-O), 1142 (C-Cl), 997, 972, 823, 770, 689, 604, 588, 570. HRMS $\left(m / z \mathrm{ESI}^{+}\right)$: found $353.1177\left(\mathrm{M}^{+}+\mathrm{H} . \mathrm{C}_{19} \mathrm{H}_{18} \mathrm{~N}_{4} \mathrm{OCl}\right.$ requires: 353.1169$)$. HPLC: $98.0 \%(t R$ : $32.3 \mathrm{~min})$.

\subsubsection{1-(4-(3-((4-Chloro-3-(trifluoromethyl)phenyl)amino)phenoxy)phenyl)guanidine hydrochloride (3)}

Following Method A (see ESI), 45 (112 $\mathrm{mg}, 0.18 \mathrm{mmol}$ ) was dissolved in $4 \mathrm{M} \mathrm{HCl}$ in dioxane $(0.54 \mathrm{~mL}, 2.16 \mathrm{mmol})$ and in additional dioxane $(0.36 \mathrm{~mL})$ until a final concentration of $0.2 \mathrm{M}$ was reached. After $8 \mathrm{~h}$ stirring at $55^{\circ} \mathrm{C}$, the reaction was adjudged complete (TLC), solvents were evaporated and the residue was purified by flash chromatography to afford the pure hydrochloride salt as a light brown solid (59 mg, 80\%). Mp: 58-60 ${ }^{\circ} \mathrm{C} . \delta_{\mathrm{H}}\left(400 \mathrm{MHz}, \mathrm{CD}_{3} \mathrm{OD}\right): 6.62(\mathrm{dd}, J=8.7,2.3 \mathrm{~Hz}, 1 \mathrm{H}, \mathrm{H}-4), 6.78(\mathrm{t}, J=2.2 \mathrm{~Hz}$, $1 \mathrm{H}, \mathrm{H}-2), 6.90(\mathrm{dd}, J=8.1,2.1 \mathrm{~Hz}, 1 \mathrm{H}, \mathrm{H}-6), 7.11\left(\mathrm{~d}, J=8.9 \mathrm{~Hz}, 2 \mathrm{H}, \mathrm{H}-8\right.$ and $\left.\mathrm{H}-8^{\prime}\right), 7.24(\mathrm{dd}, J=8.8$, $2.8 \mathrm{~Hz}, 1 \mathrm{H}, \mathrm{H}-16), 7.27-7.31$ (m, 3H, H-9, H-9' and H-5) 7.36-7.39 (m, 2H, H-12, H-15). $\delta_{\mathrm{C}}(100 \mathrm{MHz}$, $\mathrm{CD}_{3} \mathrm{OD}$ ): 109.8 (CH Ar, C-2), 113.1 (CH Ar, C-4), 114.8 (CH Ar, C-6), 116.1 (q, J = 5.6 Hz, CH Ar, C-12), 121.0 (2 CH Ar, C-8 and C-8'), 121.5 (CH Ar, C-16), 122.1 (qC, C-14), 124.4 (d, J = 272.5 Hz, qCF 3 ), 129.0 (2 CH Ar, C-9 and C-9'), 129.6 (q, J = 31.0, qC, C-13), 131.0 (qC), 131.8 (CH Ar, C-5), 133.4 (CH Ar, C-15), 144.4 (qC), 145.3 (qC), 158.2 (qC), 158.4 (qC), 159.2 (qC). $\delta_{\mathrm{F}}\left(376 \mathrm{MHz}, \mathrm{CD}_{3} \mathrm{OD}\right):-64.18$ (s). $v_{\max }(\mathrm{ATR}) / \mathrm{cm}^{-1}: 3295(\mathrm{NH}), 3163,2923,2853,2400,1664(\mathrm{C}=\mathrm{O}), 1595(\mathrm{C}=\mathrm{N}), 1504,1482,1441,1333$, 1258, $1217\left(\mathrm{CF}_{3}\right), 1127,1112(\mathrm{C}-\mathrm{Cl}), 1027,999,977,825 . \mathrm{HRMS}\left(\mathrm{m} / \mathrm{z} \mathrm{ESI}^{+}\right)$: found $421.1044\left(\mathrm{M}^{+}+\mathrm{H}\right.$. $\mathrm{C}_{20} \mathrm{H}_{17} \mathrm{ClF}_{3} \mathrm{~N}_{4} \mathrm{O}$ requires: 421.1043). HPLC: $97.8 \%$ ( $\left.t \mathrm{R}: 32.9 \mathrm{~min}\right)$.

\subsubsection{1-(4-(3-((3-(Trifluoromethyl)phenyl)amino)phenoxy)phenyl)guanidine hydrochloride (29)}

Following Method A (see ESI), 46 (371 $\mathrm{mg}, 0.63 \mathrm{mmol}$ ) was dissolved in $4 \mathrm{M} \mathrm{HCl}$ in dioxane $(1.90 \mathrm{~mL}, 7.56 \mathrm{mmol})$ and in additional dioxane $(1.25 \mathrm{~mL})$ until a final concentration of $0.2 \mathrm{M}$ was reached. After $6 \mathrm{~h}$ stirring at $55^{\circ} \mathrm{C}$, the reaction was adjudged complete (TLC), solvents were evaporated and the residue was purified by flash chromatography to afford the pure hydrochloride salt as a white solid $(242 \mathrm{mg}, 90 \%)$. Mp: $93-95^{\circ} \mathrm{C} . \delta_{\mathrm{H}}\left(400 \mathrm{MHz}, \mathrm{CD}_{3} \mathrm{OD}\right): 6.59(\mathrm{dd}, J=8.1,2.3 \mathrm{~Hz}, 1 \mathrm{H}, \mathrm{H}-4)$, $6.78(\mathrm{t}, J=2.2 \mathrm{~Hz}, 1 \mathrm{H}, \mathrm{H}-2), 6.90(\mathrm{dd}, J=7.9,1.9 \mathrm{~Hz}, 1 \mathrm{H}, \mathrm{H}-6), 7.07-7.13\left(\mathrm{~m}, 3 \mathrm{H}, \mathrm{H}-8\right.$ and $8^{\prime}$ and $\mathrm{H}-12$ or H-14), 7.26-7.30 (m, 5H, H-9 and $9^{\prime}, \mathrm{H}-12$ or H-14, H-16 and H-5 or H-15), $7.37(\mathrm{t}, J=8.3 \mathrm{~Hz}, 1 \mathrm{H}$, H-5 or H-15). $\delta_{\mathrm{C}}\left(100 \mathrm{MHz}, \mathrm{CD}_{3} \mathrm{OD}\right): 109.4(\mathrm{CH} \mathrm{Ar}, \mathrm{C}-2), 112.6$ (CH Ar, C-4), 113.9 (q, J = 4.0 Hz, CH Ar, 
C-12 or C-14), 114.6 (CH Ar, C-6), 117.3 (q, J = 4.0 Hz, CH Ar, C-12 or C-14), 119.9 (d, J = 280.7 Hz, $\left.\mathrm{qCF}_{3}\right), 120.9$ (2 CH Ar, C-8 and C-8'), 121.2 (CH Ar, C-16), 128.9 (2 CH Ar, C-9 and C-9'), 130.8 (qC), 131.1 (CH Ar, C-5 or C-15), 131.7 (CH Ar, C-5 or C-15), 132.6 (d, J = 31.9 Hz, qC, C-13), 145.7 (qC), $145.9(\mathrm{qC}), 158.3(\mathrm{qC}), 158.4(\mathrm{qC}), 159.1(\mathrm{qC}) . \delta_{\mathrm{F}}\left(376 \mathrm{MHz}, \mathrm{CD}_{3} \mathrm{OD}\right):-64.42(\mathrm{~s}) . v_{\max }(\mathrm{ATR}) / \mathrm{cm}^{-1}$ : $3301(\mathrm{NH}), 3135(\mathrm{NH}), 1665,1587(\mathrm{C}=\mathrm{N}), 1490,1486,1335(\mathrm{C}-\mathrm{N}), 1216(\mathrm{C}-\mathrm{O}), 1161,1116\left(\mathrm{CF}_{3}\right), 1067(\mathrm{C}-\mathrm{Cl})$, 976, 836, 785, 689. HRMS $\left(\mathrm{m} / z \mathrm{ESI}^{+}\right)$: found $387.1438\left(\mathrm{M}^{+}+\mathrm{H} . \mathrm{C}_{20} \mathrm{H}_{18} \mathrm{~N}_{4} \mathrm{OF}_{3}\right.$ requires: 387.1433). HPLC: $97.5 \%$ ( $t \mathrm{R}: 31.7 \mathrm{~min})$.

\subsubsection{1-(4-(3-((3-(Pentafluorosulfanyl)phenyl)amino)phenoxy)phenyl)guanidine hydrochloride (30)}

Following Method A (see ESI), $47(272 \mathrm{mg}, 0.42 \mathrm{mmol})$ was dissolved in $4 \mathrm{M} \mathrm{HCl}$ in dioxane $(1.27 \mathrm{~mL}, 5.06 \mathrm{mmol})$ and in additional dioxane $(0.83 \mathrm{~mL})$ until a final concentration of $0.2 \mathrm{M}$ was reached. After $6 \mathrm{~h}$ stirring at $55^{\circ} \mathrm{C}$, the reaction was adjudged complete (TLC), solvents were evaporated and the residue was purified by silica gel chromatography $\left(\mathrm{CHCl}_{3}: \mathrm{MeOH}\right)$ to afford the pure hydrochloride salt as an orange solid $(127 \mathrm{mg}, 62 \%)$. Mp: $104-106{ }^{\circ} \mathrm{C} . \delta_{\mathrm{H}}\left(400 \mathrm{MHz}, \mathrm{CD}_{3} \mathrm{OD}\right): 6.61(\mathrm{dd}, J=8.2$, $2.3 \mathrm{~Hz}, 1 \mathrm{H}, \mathrm{H}-4), 6.78(\mathrm{t}, J=2.2$. Hz, $1 \mathrm{H}, \mathrm{H}-2), 6.90(\mathrm{dd}, J=8.1,2.1 \mathrm{~Hz}, 1 \mathrm{H}, \mathrm{H}-6), 7.11(\mathrm{~d}, J=8.9 \mathrm{~Hz}$, H-8 and H- $\left.8^{\prime}\right)$, 7.22-7.31 (m, 5H, H-9 and H-9', H-5 or H-15, H-14 and H-16), 7.34-7.38 (m, 1H, H-5 or $\mathrm{H}-15), 7.44(\mathrm{t}, J=2.2 \mathrm{~Hz}, 1 \mathrm{H}, \mathrm{H}-12) . \delta_{\mathrm{C}}\left(100 \mathrm{MHz}, \mathrm{CD}_{3} \mathrm{OD}\right): 109.6(\mathrm{CH} \mathrm{Ar}, \mathrm{C}-2), 112.9$ (CH Ar, C-4), 114.6 (CH Ar, C-6), 114.9 (p, J = 4.6 Hz, CH Ar, C-12), 118.0 (p, J = 4.7 Hz, CH Ar, C-14), 120.8 (CH Ar, C-16), 120.9 (2 CH Ar, C-8 and C-8'), 128.8 (2 CH Ar, C-9 and C-9'), 130.6 (CH Ar, C-5 or C-15), 130.8 (qC), 131.8 (CH Ar, C-5 or C-15), 145.6 (qC), 145.7 (qC), 155.9 (p, J = 16.4 Hz, qC, C-13), 158.2 (qC), $158.3(\mathrm{qC}), 159.2(\mathrm{qC}) . \delta_{\mathrm{F}}\left(376 \mathrm{MHz}, \mathrm{CD}_{3} \mathrm{OD}\right):-64.34(\mathrm{~s}) . v_{\max }(\mathrm{ATR}) / \mathrm{cm}^{-1}: 3273(\mathrm{NH}), 3150(\mathrm{NH})$, 1669, $1593(\mathrm{C}=\mathrm{N}), 1487(\mathrm{C}-\mathrm{N}), 1218(\mathrm{C}-\mathrm{O}), 834\left(\mathrm{SF}_{5}\right), 567$. HRMS $\left(\mathrm{m} / \mathrm{z} \mathrm{ESI}^{+}\right)$: found $445.1124\left(\mathrm{M}^{+}+\mathrm{H}\right.$. $\mathrm{C}_{19} \mathrm{H}_{18} \mathrm{~N}_{4} \mathrm{OSF}_{5}$ requires: 445.1121). HPLC: $95.4 \%$ ( $\left.t \mathrm{R}: 32.3 \mathrm{~min}\right)$.

4.2.12. 1-(4-(3-((4-Chloro-3-(trifluormethyl)phenyl)amino)-5-fluorophenoxy)phenyl)guanidine hydrochloride (36)

Following Method A (see ESI), 48 (166 mg, $0.26 \mathrm{mmol}$ ) was dissolved in $4 \mathrm{M} \mathrm{HCl}$ in dioxane $(0.78 \mathrm{~mL}, 3.12 \mathrm{mmol})$ and in additional dioxane $(0.51 \mathrm{~mL})$ until a final concentration of $0.2 \mathrm{M}$ was reached. After $8 \mathrm{~h}$ stirring at $55^{\circ} \mathrm{C}$, the reaction was adjudged complete (TLC), solvents were evaporated and the residue was purified by silica gel chromatography $\left(\mathrm{CHCl}_{3}: \mathrm{MeOH}\right)$ to afford the pure hydrochloride salt as a light brown solid (114 mg, 92\%). Mp: $92-94{ }^{\circ} \mathrm{C} . \delta_{\mathrm{H}}\left(600 \mathrm{MHz}, \mathrm{CD}_{3} \mathrm{OD}\right): 6.31(\mathrm{dt}, J=9.9$, $2.1 \mathrm{~Hz}, 1 \mathrm{H}, \mathrm{H}-4), 6.55(\mathrm{~s}, 1 \mathrm{H}, \mathrm{H}-2), 6.58(\mathrm{dt}, J=10.7,2.0 \mathrm{~Hz}, 1 \mathrm{H}, \mathrm{H}-6), 7.16(\mathrm{~d}, J=8.8 \mathrm{~Hz}, 2 \mathrm{H}, \mathrm{H}-8$ and $\left.\mathrm{H}-8^{\prime}\right), 7.29(\mathrm{dd}, J=8.8,2.7 \mathrm{~Hz}, 1 \mathrm{H}, \mathrm{H}-16), 7.32\left(\mathrm{~d}, J=8.8 \mathrm{~Hz}, 2 \mathrm{H}, \mathrm{H}-9\right.$ and $\left.\mathrm{H}-9^{\prime}\right), 7.40(\mathrm{~d}, J=2.6 \mathrm{~Hz}$, 1H, H-12), 7.43 (d, J = 8.7 Hz, 1H, H-15). $\delta_{\mathrm{C}}\left(150 \mathrm{MHz}, \mathrm{CD}_{3} \mathrm{OD}\right): 99.4$ (d, J = 25.7 Hz, CH Ar, C-4), $100.3(\mathrm{~d}, J=25.5 \mathrm{~Hz}, \mathrm{CH}$ Ar, C-6), 103.8 (d, $J=2.6 \mathrm{~Hz}, \mathrm{CH} \mathrm{Ar}, \mathrm{C}-2), 117.4(\mathrm{q}, J=5.5 \mathrm{~Hz}, \mathrm{CH} \mathrm{Ar}$, C-12), 121.8 (2 CH Ar, C-8 and C-8'), 122.7 (CH Ar, C-16), 123.4 (qC, C-14), 124.3 (d, J = 272.2 Hz, $\left.\mathrm{qCF}_{3}\right), 128.9$ (2 CH Ar, C-9 and C-9'), 129.8 (q, $\left.J=31.0, \mathrm{qC}, \mathrm{C}-13\right), 131.7(\mathrm{qC}), 133.5(\mathrm{CH} \mathrm{Ar}, \mathrm{C}-15)$, $143.4(\mathrm{qC}), 146.7(\mathrm{~d}, J=13.2 \mathrm{~Hz}, \mathrm{qC}, \mathrm{C}-1$ or C-3), $157.1(\mathrm{qC}), 158.4(\mathrm{qC}), 160.7(\mathrm{~d}, J=13.7 \mathrm{~Hz}, \mathrm{qC}, \mathrm{C}-1$ or C-3), $165.8(\mathrm{~d}, J=243.4 \mathrm{~Hz}, \mathrm{qC}, \mathrm{C}-5) . \delta_{\mathrm{F}}\left(376 \mathrm{MHz}, \mathrm{CD}_{3} \mathrm{OD}\right):-64.67(\mathrm{~s}),-112.53(\mathrm{~s}) . v_{\max }(\mathrm{ATR}) / \mathrm{cm}^{-1}$ : $3285(\mathrm{NH}), 3139(\mathrm{NH}), 1666,1601(\mathrm{C}=\mathrm{N})$, 1504, 1476, $1323\left(\mathrm{CF}_{3}\right), 1216(\mathrm{C}-\mathrm{O}), 1112(\mathrm{C}-\mathrm{F}), 1020$ (C-Cl), 994, 823, 660. HRMS $\left(m / z \mathrm{ESI}^{+}\right)$: found $439.0945\left(\mathrm{M}^{+}+\mathrm{H} . \mathrm{C}_{20} \mathrm{H}_{16} \mathrm{~N}_{4} \mathrm{OF}_{4} \mathrm{Cl}\right.$ requires: 439.0943). HPLC: 95.7\% ( $t \mathrm{R}: 33.1 \mathrm{~min})$.

4.2.13. 1-(3,4-Di-fluorophenyl)-3-(3-((6-guanidinopyridin-3-yl)oxy)phenyl)guanidine dihydrochloride (49)

Following Method A (see ESI), 61 (176 mg, $0.25 \mathrm{mmol}$ ) was dissolved in $4 \mathrm{M} \mathrm{HCl}$ in dioxane $(1.14 \mathrm{~mL}, 4.54 \mathrm{mmol})$ and in additional dioxane $(0.11 \mathrm{~mL})$ until a final concentration of $0.2 \mathrm{M}$ was reached. After $8 \mathrm{~h}$ stirring at $55^{\circ} \mathrm{C}$, the reaction was adjudged complete (TLC), solvents were evaporated and the residue was purified by silica gel chromatography $\left(\mathrm{CHCl}_{3}: \mathrm{MeOH}\right)$ to afford the pure hydrochloride salt as a white solid (101 mg, 84\%). Mp: decomp. above $110^{\circ} \mathrm{C}$. $\delta_{\mathrm{H}}\left(400 \mathrm{MHz}, \mathrm{CD}_{3} \mathrm{OD}\right): 6.62(\mathrm{dd}, J=7.5$, 
$2.4 \mathrm{~Hz}, 1 \mathrm{H}, \mathrm{H}-4), 6.77-6.81$ (m, 1H, H-17), 6.93 (dd, J = 8.0, $1.8 \mathrm{~Hz}, 1 \mathrm{H}, \mathrm{H}-6), 6.99$ (d, J = 8.9 Hz, 1H, $\mathrm{H}-9), 7.00-7.13(\mathrm{~m}, 3 \mathrm{H}, \mathrm{H}-2, \mathrm{H}-13$ and H-16), 7.25 (t, $J=8.1 \mathrm{~Hz}, 1 \mathrm{H}, \mathrm{H}-5), 7.49(\mathrm{dd}, J=8.9,2.9 \mathrm{~Hz}, 1 \mathrm{H}$, $\mathrm{H}-8), 8.05(\mathrm{~d}, J=2.9 \mathrm{~Hz}, 1 \mathrm{H}, \mathrm{H}-11) . \delta_{\mathrm{C}}\left(100 \mathrm{MHz}, \mathrm{CD}_{3} \mathrm{OD}\right): 112.0(\mathrm{~d}, J=18.8 \mathrm{~Hz}, \mathrm{CH} \mathrm{Ar}, \mathrm{C}-13 \mathrm{or} \mathrm{C}-16)$, 112.4 (CH Ar, C-2), 113.0 (CH Ar, C-4), 116.4 (CH Ar, C-9), 118.0 (CH Ar, C-6), 118.1 (d, J = 17.9 Hz, CH Ar, C-13 or C-16), 119.1 (dd, J = 5.6, 3.1 Hz, CH Ar, C-17), 131.3 (CH Ar, C-5), 131.4 (CH Ar, C-8), 138.5 (CH Ar, C-11), 143.9 (dd, J = 7.4, 2.2 Hz, qC, C-12), 146.6 (qC), 147.2 (dd, J = 240.4, $12.9 \mathrm{~Hz}$, qC, C-14 or C-15), 150.1 (qC), 151.1 (qC), $151.4(\mathrm{dd}, J=245.1,13.4 \mathrm{~Hz}, \mathrm{qC}, \mathrm{C}-14$ or C-15), 152.5 (qC), $157.4(\mathrm{qC}), 159.0(\mathrm{qC}) . \delta_{\mathrm{F}}\left(376 \mathrm{MHz}, \mathrm{CD}_{3} \mathrm{OD}\right):-139.72(\mathrm{~m}),-149.19(\mathrm{~m}) . v_{\max }(\mathrm{ATR}) / \mathrm{cm}^{-1}: 3313(\mathrm{NH})$, $3154(\mathrm{NH}), 2922,2861,1682,1625$ (C=N), 1507, 1473 (C-F), 1375, 1228 (C-F), 1166, 1146 (C-O), 866, 830, 770, 570, 557. HRMS $\left(\mathrm{m} / \mathrm{z} \mathrm{ESI}^{+}\right)$: found $398.1548\left(\mathrm{M}^{+}+\mathrm{H} \mathrm{C}_{19} \mathrm{H}_{18} \mathrm{~N}_{7} \mathrm{OF}_{2}\right.$ requires: 398.1541). HPLC: $99.8 \%$ ( $t R: 23.6 \mathrm{~min})$.

4.2.14. 1-(2-Fluoro-4-iodophenyl)-3-(3-((6-guanidinopyridin-3-yl)oxy)phenyl)guanidine dihydrochloride (50)

Following Method A (see ESI), 62 (104 $\mathrm{mg}, 0.13 \mathrm{mmol}$ ) was dissolved in $4 \mathrm{M} \mathrm{HCl}$ in dioxane $(0.58 \mathrm{~mL}, 2.32 \mathrm{mmol})$ and in additional dioxane $(0.10 \mathrm{~mL})$ until a final concentration of $0.2 \mathrm{M}$ was reached. After $8 \mathrm{~h}$ stirring at $55^{\circ} \mathrm{C}$, the reaction was adjudged complete (TLC), solvents were evaporated and the residue was purified by silica gel chromatography $\left(\mathrm{CHCl}_{3}: \mathrm{MeOH}\right)$ to afford the pure hydrochloride salt as a white solid $(67 \mathrm{mg}, 89 \%)$. Mp: decomp. above $120^{\circ} \mathrm{C}$. $\delta_{\mathrm{H}}\left(400 \mathrm{MHz}, \mathrm{CD}_{3} \mathrm{OD}\right): 6.98$ (ddd, $J=8.3$, 2.4, $0.7 \mathrm{~Hz}, 1 \mathrm{H}, \mathrm{H}-4), 7.02(\mathrm{t}, J=2.2 \mathrm{~Hz}, 1 \mathrm{H}, \mathrm{H}-2), 7.11-7.18$ (m, 3H, H-5 or H-16, H-6 and H-9), $7.46(\mathrm{t}, J=8.1 \mathrm{~Hz}, 1 \mathrm{H}, \mathrm{H}-5$ or H-16), 7.61-7.64 (m, 2H, H-17 and H-8), $7.67(\mathrm{dd}, J=9.7,1.8 \mathrm{~Hz}, 1 \mathrm{H}$, $\mathrm{H}-14), 8.16(\mathrm{~d}, J=2.9 \mathrm{~Hz}, 1 \mathrm{H}, \mathrm{H}-11) . \delta_{\mathrm{C}}\left(100 \mathrm{MHz}, \mathrm{CD}_{3} \mathrm{OD}\right): 92.7$ (qC, C-15), 115.5 (CH Ar, C-2), 115.6 (CH Ar, C-9), 117.6 (CH Ar, C-4), 120.9 (CH Ar, C-6), 127.2 (d, J=22.2 Hz, CH Ar, C-14), $127.3(\mathrm{~d}, J=14.1 \mathrm{~Hz}, \mathrm{qC}, \mathrm{C}-12), 130.6$ (CH Ar, C-5 or C-16), 132.1 (CH Ar, C-8), 132.5 (CH Ar, C-5 or C-16), 136.0 (CH Ar, J = 3.9 Hz, C-17), 138.7 (qC), 139.1 (CH Ar, C-11), 149.2 (qC), 151.2 (qC), 156.2 (qC), 156.9 (qC), $157.9(\mathrm{qAr}, J=253.9 \mathrm{~Hz}, \mathrm{C}-13), 159.4(\mathrm{qC}) . \delta_{\mathrm{F}}\left(376 \mathrm{MHz} \mathrm{CD}_{3} \mathrm{OD}\right):-121.55(\mathrm{t}, J=8.3 \mathrm{~Hz})$. $v_{\max }(\mathrm{ATR}) / \mathrm{cm}^{-1}: 3277(\mathrm{NH}), 3122(\mathrm{NH}), 2923,2849,1680,1660,1623-1570(\mathrm{C}=\mathrm{N}), 1474(\mathrm{C}-\mathrm{F})$, 1227 (C-O), 1160, 1026, 945, 600 (C-I). HRMS (m/z ESI $\left.{ }^{+}\right)$: found $506.0609\left(\mathrm{M}^{+}+\mathrm{H} . \mathrm{C}_{19} \mathrm{H}_{18} \mathrm{~N}_{7} \mathrm{OFI}\right.$ requires: 506.0602). HPLC: $98.1 \%$ ( $t \mathrm{R}: 25.7 \mathrm{~min})$.

4.2.15. 1-(4-Bromophenyl)-3-(3-((6-guanidinopyridin-3-yl)oxy)phenyl)guanidine dihydrochloride (51)

Following Method A (see ESI), 63 (184 mg, $0.24 \mathrm{mmol}$ ) was dissolved in $4 \mathrm{M} \mathrm{HCl}$ in dioxane $(1.08 \mathrm{~mL}, 4.4 \mathrm{mmol})$ and in additional dioxane $(0.12 \mathrm{~mL})$ until a final concentration of $0.2 \mathrm{M}$ was reached. After $8 \mathrm{~h}$ stirring at $55^{\circ} \mathrm{C}$, the reaction was adjudged complete (TLC), solvents were evaporated and the residue was purified by silica gel chromatography $\left(\mathrm{CHCl}_{3}: \mathrm{MeOH}\right)$ to afford the pure hydrochloride salt as a white solid (113 mg, 92\%). Mp: decomp. above $124{ }^{\circ} \mathrm{C}$. $\delta_{\mathrm{H}}\left(400 \mathrm{MHz}, \mathrm{CD}_{3} \mathrm{OD}\right): 6.99-7.01(\mathrm{~m}, 1 \mathrm{H}$, $\mathrm{H}-4), 7.04$ (bs, 1H, H-2), 7.14-7.16 (m, 2H, H-6 and H-9), 7.28 (d, $J=8.5$ Hz, 2H, H-13 and H-13' or H-14 and $\left.\mathrm{H}-14^{\prime}\right), 7.48(\mathrm{t}, J=8.1 \mathrm{~Hz}, 1 \mathrm{H}, \mathrm{H}-5), 7.60-7.63\left(\mathrm{~m}, 3 \mathrm{H}, \mathrm{H}-13\right.$ and $\mathrm{H}-13^{\prime}$ or $\mathrm{H}-14$ and $\mathrm{H}-14^{\prime}$ and $\left.\mathrm{H}-8\right)$, $8.16(\mathrm{~d}, J=2.6 \mathrm{~Hz}, 1 \mathrm{H}, \mathrm{H}-11) . \delta_{\mathrm{C}}\left(100 \mathrm{MHz}, \mathrm{CD}_{3} \mathrm{OD}\right): 115.6(\mathrm{CH} \mathrm{Ar}, \mathrm{C}-6$ or C-9), $115.8(\mathrm{CH} \mathrm{Ar}, \mathrm{C}-2)$, 118.0 (CH Ar, C-4), 121.1 (CH Ar, C-6 or C-9), 121.7 (qC, C-15), 127.9 (CH Ar, C-13 and C-13' or C-14 and C-14'), 132.1 (CH Ar, C-8), 132.5 (CH Ar, C-5), 134.1 (CH Ar, C-13 and C-13' or C-14 and C-14'), 135.7 (qC), 138.2 (qC), 139.0 (CH Ar, C-11), 149.2 (qC), 151.2 (qC), 156.1 (qC), 156.8 (qC), 159.4 (qC). $v_{\max }(\mathrm{ATR}) / \mathrm{cm}^{-1}: 3256(\mathrm{NH}), 3114(\mathrm{NH})$, 2971, 1680, 1660, $1619(\mathrm{C}=\mathrm{N}), 1566(\mathrm{C}=\mathrm{N})$, 1474, $1376(\mathrm{C}-\mathrm{N})$, 1226 (C-O), 1069 (C-Br), 1010, 832, 637-584. HRMS ( $\left.\mathrm{m} / \mathrm{z} \mathrm{ESI}^{+}\right)$: found $440.0837\left(\mathrm{M}^{+}+\mathrm{H} . \mathrm{C}_{19} \mathrm{H}_{19} \mathrm{~N}_{7} \mathrm{OBr}\right.$ requires: 440.0834$)$. HPLC: $97.5 \%$ ( $t \mathrm{R}: 25.2 \mathrm{~min})$.

4.2.16. 1-(4-Bromo-3-(trifluoromethyl)phenyl)-3-(3-((6-guanidinopyridin-3-yl)oxy)phenyl) guanidine dihydrochloride (52)

Following Method A (see ESI), 64 (358 $\mathrm{mg}, 0.44 \mathrm{mmol}$ ) was dissolved in $4 \mathrm{M} \mathrm{HCl}$ in dioxane $(2 \mathrm{~mL}, 7.97 \mathrm{mmol})$ and in additional dioxane $(0.2 \mathrm{~mL})$ until a final concentration of $0.2 \mathrm{M}$ was reached. 
After $8 \mathrm{~h}$ stirring at $55{ }^{\circ} \mathrm{C}$, the reaction was adjudged complete (TLC), solvents were evaporated and the residue was purified by silica gel chromatography $\left(\mathrm{CHCl}_{3}: \mathrm{MeOH}\right)$ to afford the pure hydrochloride salt as a white solid $(225 \mathrm{mg}, 88 \%)$. Mp: decomp. above $170{ }^{\circ} \mathrm{C}$. $\delta_{\mathrm{H}}\left(400 \mathrm{MHz}, \mathrm{CD}_{3} \mathrm{OD}\right): 6.66(\mathrm{dd}, J=8.1$, $2.4 \mathrm{~Hz}, 1 \mathrm{H}, \mathrm{H}-4), 6.96(\mathrm{dd}, J=8.0,1.9 \mathrm{~Hz}, 1 \mathrm{H}, \mathrm{H}-6), 7.04(\mathrm{~d}, J=8.9 \mathrm{~Hz}, 1 \mathrm{H}, \mathrm{H}-9), 7.08(\mathrm{t}, J=2.1 \mathrm{~Hz}$, $1 \mathrm{H}, \mathrm{H}-2), 7.20(\mathrm{dd}, J=8.6,2.5 \mathrm{~Hz}, 1 \mathrm{H}, \mathrm{H}-17), 7.28(\mathrm{t}, J=8.1 \mathrm{~Hz}, 1 \mathrm{H}, \mathrm{H}-5), 7.48(\mathrm{~d}, J=2.5,1 \mathrm{H}$, $\mathrm{H}-13), 7.56(\mathrm{dd}, J=8.9,2.9 \mathrm{~Hz}, 1 \mathrm{H}, \mathrm{H}-8), 7.60(\mathrm{~d}, J=8.6 \mathrm{~Hz}, 1 \mathrm{H}, \mathrm{H}-16), 8.10(\mathrm{~d}, J=2.7 \mathrm{~Hz}, 1 \mathrm{H}$, H-11). $\delta_{\mathrm{C}}\left(100 \mathrm{MHz}, \mathrm{CD}_{3} \mathrm{OD}\right): 111.8$ (d, $\left.J=1.8 \mathrm{~Hz}, \mathrm{qC}, \mathrm{C}-15\right), 112.4(\mathrm{CH} \mathrm{Ar}, \mathrm{C}-2), 113.3$ (CH Ar, C-4), 115.5 (CH Ar, C-9), 117.8 (CH Ar, C-6), 122.4 (q, J = 5.5 Hz, CH Ar, C-13), 124.4 (d, J = 272.6 Hz, $\left.\mathrm{qCF}_{3}\right), 127.7$ (CH Ar, C-17), 130.9 (d, $\left.J=30.8 \mathrm{~Hz}, \mathrm{qC}, \mathrm{C}-14\right), 131.4(\mathrm{CH} \mathrm{Ar}, \mathrm{C}-5), 131.6$ (CH Ar, C-8), 136.6 (CH Ar, C-16), 138.6 (CH Ar, C-11), 146.1 (qC), 147.2 (qC), 148.9 (qC), 151.8 (qC), $152.4(\mathrm{qC})$, $156.9(\mathrm{qC}), 159.0(\mathrm{qC}) . \delta_{\mathrm{F}}\left(376 \mathrm{MHz}, \mathrm{CD}_{3} \mathrm{OD}\right):-63.96(\mathrm{~s}) . v_{\max }(\mathrm{ATR}) / \mathrm{cm}^{-1}: 3281(\mathrm{NH}), 3142(\mathrm{NH})$, 2922, 2849, 1680, $1625(\mathrm{C}=\mathrm{N}), 1566(\mathrm{C}=\mathrm{N}), 1473,1319,1227\left(\mathrm{CF}_{3}\right), 1129$ (C-Br), 1023, 832, 592-583. HRMS $\left(\mathrm{m} / \mathrm{z} \mathrm{ESI}^{+}\right)$: found $508.0710\left(\mathrm{M}^{+}+\mathrm{H} . \mathrm{C}_{20} \mathrm{H}_{18} \mathrm{~N}_{7} \mathrm{OF}_{3} \mathrm{Br}\right.$ requires: 508.0708$)$. HPLC: $99.8 \%$ ( $t \mathrm{R}$ : $27.5 \mathrm{~min})$.

4.2.17. 1-(4-Chloro-3-(trifluoromethyl)phenyl)-3-(3-((6-guanidinopyridin-3-yl)oxy)phenyl) guanidine dihydrochloride (2)

Following Method A (see ESI), $65(113 \mathrm{mg}, 0.15 \mathrm{mmol})$ was dissolved in $4 \mathrm{M} \mathrm{HCl}$ in dioxane $(0.67 \mathrm{~mL}, 2.70 \mathrm{mmol})$ and in additional dioxane $(0.10 \mathrm{~mL})$ until a final concentration of $0.2 \mathrm{M}$ was reached. After $6 \mathrm{~h}$ stirring at $55^{\circ} \mathrm{C}$, the reaction was adjudged complete (TLC), solvents were evaporated and the residue was purified by flash chromatography to afford the pure hydrochloride salt as a white solid (63 mg, 79\%). Mp: $169-171^{\circ} \mathrm{C} . \delta_{\mathrm{H}}\left(400 \mathrm{MHz}, \mathrm{CD}_{3} \mathrm{OD}\right): 6.93(\mathrm{dd}, J=8.3,2.3 \mathrm{~Hz}, 1 \mathrm{H}, \mathrm{H}-4)$, $7.06(\mathrm{t}, J=2.1 \mathrm{~Hz}, 1 \mathrm{H}, \mathrm{H}-2), 7.11-7.13(\mathrm{~m}, 2 \mathrm{H}, \mathrm{H}-6$ and H-9), $7.44(\mathrm{t}, J=8.2 \mathrm{~Hz}, 1 \mathrm{H}, \mathrm{H}-5), 7.53(\mathrm{dd}, J=8.6$, $2.5 \mathrm{~Hz}, 1 \mathrm{H}, \mathrm{H}-17), 7.60-7.65(\mathrm{~m}, 2 \mathrm{H}, \mathrm{H}-16$ and $\mathrm{H}-8), 7.69(\mathrm{~d}, J=2.4 \mathrm{~Hz}, 1 \mathrm{H}, \mathrm{H}-13), 8.15(\mathrm{~d}, J=2.9 \mathrm{~Hz}, 1 \mathrm{H}$, H-11). $\delta_{\mathrm{C}}\left(100 \mathrm{MHz}, \mathrm{CD}_{3} \mathrm{OD}\right.$ ): 115.1 ( $\left.\mathrm{CH} \mathrm{Ar}, \mathrm{C}-2\right), 115.6$ (CH Ar, C-9), 117.1 (CH Ar, C-4), 120.5 (CH Ar, C-6), 123.9 (d, $\left.J=272.5 \mathrm{~Hz}, \mathrm{qCF}_{3}\right) 124.5$ (q, J = 5.5 Hz, CH Ar, C-13), 129.9 (qC, C-15), 130.1 (CH Ar, C-17), 130.2 (d, J = 34.7 Hz, qC, C-14), 132.0 (CH Ar, C-8 or C-16), 132.3 (CH Ar, C-5), 134.0 (CH Ar, C-8 or C-16), 138.3 (qC), 139.0 (CH Ar, C-11), 139.7 (qC), 149.1 (qC), 151.3 (qC), 155.5 (qC), 156.9 (qC), $159.3(\mathrm{qC}) . \delta_{\mathrm{F}}\left(376 \mathrm{MHz}, \mathrm{CD}_{3} \mathrm{OD}\right):-64.24(\mathrm{~s}) . v_{\max }(\mathrm{ATR}) / \mathrm{cm}^{-1}: 3297(\mathrm{NH}), 3121(\mathrm{NH}), 2923,2854$, $1625(\mathrm{C}=\mathrm{N}), 1581(\mathrm{C}=\mathrm{N}), 1474\left(\mathrm{CF}_{3}\right), 1320,1227(\mathrm{C}-\mathrm{O}), 1130(\mathrm{C}-\mathrm{Cl}), 1032,832,589,557$. HRMS $\left(\mathrm{m} / z \mathrm{ESI}^{+}\right)$: found: $464.1222\left(\mathrm{M}^{+}+\mathrm{H} . \mathrm{C}_{20} \mathrm{H}_{18} \mathrm{~N}_{7} \mathrm{OF}_{3} \mathrm{Cl}\right.$ requires: 464.1213). HPLC: 96.9\% ( $t \mathrm{R}: 26.8 \mathrm{~min}$ ).

4.2.18. 1-(5-(3-((4-Chloro-3-(trifluoromethyl)phenyl)amino)phenoxy)pyridin-2-yl)guanidine hydrochloride (4)

Following Method A (see ESI), 69 (200 mg, $0.32 \mathrm{mmol})$ was dissolved in $4 \mathrm{M} \mathrm{HCl}$ in dioxane $(0.96 \mathrm{~mL}, 3.86 \mathrm{mmol})$ and in additional dioxane $(0.65 \mathrm{~mL})$ until a final concentration of $0.2 \mathrm{M}$ was reached. After $8 \mathrm{~h}$ stirring at $55^{\circ} \mathrm{C}$, the reaction was adjudged complete (TLC), solvents were evaporated and the residue was purified by silica gel chromatography $\left(\mathrm{CHCl}_{3}: \mathrm{MeOH}\right)$ to afford the pure hydrochloride salt as a white solid (136 mg, 93\%). Mp: $89-91^{\circ} \mathrm{C} . \delta_{\mathrm{H}}\left(400 \mathrm{MHz}, \mathrm{CD}_{3} \mathrm{OD}\right): 6.60(\mathrm{dd}, J=8.2,2.3 \mathrm{~Hz}$, $1 \mathrm{H}, \mathrm{H}-4), 6.75(\mathrm{t}, J=2.2 \mathrm{~Hz}, 1 \mathrm{H}, \mathrm{H}-2), 6.90(\mathrm{dd}, J=8.1,2.0 \mathrm{~Hz}, 1 \mathrm{H}, \mathrm{H}-6), 7.08$ (d, $J=8.9 \mathrm{~Hz}, 1 \mathrm{H}, \mathrm{H}-9)$, $7.24(\mathrm{dd}, J=8.7,2.7 \mathrm{~Hz}, 1 \mathrm{H}, \mathrm{H}-17), 7.29(\mathrm{t}, J=8.1 \mathrm{~Hz}, 1 \mathrm{H}, \mathrm{H}-5), 7.37-7.39(\mathrm{~m}, 2 \mathrm{H}, \mathrm{H}-13$ and H-16), $7.59(\mathrm{dd}, J=8.9,2.9 \mathrm{~Hz}, 1 \mathrm{H}, \mathrm{H}-8), 8.13(\mathrm{~d}, J=2.9 \mathrm{~Hz}, 1 \mathrm{H}, \mathrm{H}-11) . \delta_{\mathrm{C}}\left(100 \mathrm{MHz}, \mathrm{CD}_{3} \mathrm{OD}\right): 108.7(\mathrm{CH} \mathrm{Ar}$, C-2), 112.2 (CH Ar, C-4), 114.7 (CH Ar, C-6), 115.5 (CH Ar, C-9), 116.2 (q, J = 5.5 Hz, CH Ar, C-13), 121.8 (CH Ar, C-17), 122.4 (qC, C-15), 124.3 (d, J = 272.4 Hz, qCF 3 ), 129.6 (d, J = 31.0 Hz, qC, C-14), 131.8 (CH Ar, C-8), 132.0 (CH Ar, C-5), 133.4 (CH Ar, C-16), 138.7 (CH Ar, C-11), 144.2 (qC), 145.6 (qC), $148.8(\mathrm{qC}), 151.8(\mathrm{qC}), 156.9(\mathrm{qC}), 159.4(\mathrm{qC}) . \delta_{\mathrm{F}}\left(376 \mathrm{MHz}, \mathrm{CD}_{3} \mathrm{OD}\right):-64.15(\mathrm{~s}) . v_{\max }(\mathrm{ATR}) / \mathrm{cm}^{-1}$ : $3264(\mathrm{NH}), 2923,2863,1684,1629,1595,1474(\mathrm{C}=\mathrm{N}), 1400,1332,1229(\mathrm{C}-\mathrm{O}), 1129\left(\mathrm{CF}_{3}\right), 1115(\mathrm{C}-\mathrm{Cl})$, 977, 998. HRMS $\left(\mathrm{m} / \mathrm{z} \mathrm{ESI}^{+}\right)$: found $422.0987\left(\mathrm{M}^{+}+\mathrm{H} . \mathrm{C}_{19} \mathrm{H}_{16} \mathrm{~N}_{5} \mathrm{OClF}_{3}\right.$ requires: 422.0995). HPLC: $98.6 \%$ (tR: $33.3 \mathrm{~min})$. 
4.2.19. 4-(3-((4-Chloro-3-(trifluoromethyl)phenyl)amino)phenoxy)phenyl carbamimidate hydrochloride (70)

To a stirred solution of $74\left(205 \mathrm{mg}, 0.33 \mathrm{mmol}\right.$, 1eq) in EtOAc was added $\mathrm{SnCl}_{4}(0.15 \mathrm{~mL}$, $1.32 \mathrm{mmol}, 4 \mathrm{eq})$. After $2 \mathrm{~h}$ of stirring at room temperature, the solvent and the excess of $\mathrm{SnCl}_{4} \mathrm{Were}$ evaporated in vacuo. The remaining liquid was purified by silica gel chromatography $\left(\mathrm{CHCl}_{3}: \mathrm{Acetone}\right)$ to afford the pure hydrochloride salt $(130 \mathrm{mg}, 86 \%)$ as a colourless gum. $\delta_{\mathrm{H}}\left(400 \mathrm{MHz}, \mathrm{DMSO}-d_{6}\right)$ : $6.61(\mathrm{dd}, J=7.6,2.3 \mathrm{~Hz}, 1 \mathrm{H}, \mathrm{H}-4), 6.76(\mathrm{t}, J=2.2 \mathrm{~Hz}, 1 \mathrm{H}, \mathrm{H}-2), 6.92(\mathrm{dd}, J=7.8,1.7 \mathrm{~Hz}, 1 \mathrm{H}, \mathrm{H}-6)$, $7.16\left(\mathrm{~d}, J=9.1 \mathrm{~Hz}, 2 \mathrm{H}, \mathrm{H}-8\right.$ and $\mathrm{H}-8^{\prime}$ or $\mathrm{H}-9$ and $\left.\mathrm{H}-9^{\prime}\right), 7.30-7.34(\mathrm{~m}, 2 \mathrm{H}, \mathrm{H}-5$ and $\mathrm{H}-16)$, $7.37\left(\mathrm{~d}, J=9.0 \mathrm{~Hz}, 2 \mathrm{H}, \mathrm{H}-8\right.$ and $\mathrm{H}-8^{\prime}$ or $\mathrm{H}-9$ and $\left.\mathrm{H}-9^{\prime}\right), 7.40(\mathrm{~d}, J=2.7 \mathrm{~Hz}, 1 \mathrm{H}, \mathrm{H}-12), 7.50(\mathrm{~d}, J=8.8 \mathrm{~Hz}$, $1 \mathrm{H}, \mathrm{H}-15), 8.61$ (bs, $4 \mathrm{H}, \mathrm{NH}), 8.88$ (bs, NH). $\delta_{\mathrm{C}}\left(100 \mathrm{MHz}, \mathrm{DMSO}-d_{6}\right): 107.8$ (CH Ar, C-2), $111.2(\mathrm{CH} \mathrm{Ar}$, C-4), 113.1 (CH Ar, C-6), 114.7 (q, $J=5.5$ Hz, CH Ar, C-12), 119.4 (qC, C-14), 120.4 (CH Ar, C-5 or C-16), 120.5 (2 CH Ar, C-8 and C-8' or C-9 and C-9'), 122.0 (d, J = 227.5 Hz, qCF 3 ), 123.1 (2 CH Ar, C-8 and C-8' or C-9 and C-9'), $127.2(\mathrm{~d}, J=30.7 \mathrm{~Hz}, \mathrm{qC}, \mathrm{C}-13), 130.9(\mathrm{CH}$ Ar, C-5 or C-16), 132.7 (CH Ar, C-15), 142.8 (qC), 143.5 (qC), 145.2 (qC), 155.2 (qC), 157.6 (qC), 161.1 (qC). $\delta_{F}\left(376 \mathrm{MHz}, \mathrm{CD}_{3} \mathrm{OD}\right):-61.59$ (s). $v_{\max }(\mathrm{ATR}) / \mathrm{cm}^{-1}: 3285(\mathrm{NH}), 2924,2854,1693,1655,1593(\mathrm{C}=\mathrm{N}), 1481(\mathrm{C}-\mathrm{N}), 1400,1258,1231,1195$, 1175 (C-O), $1128\left(\mathrm{CF}_{3}\right), 1111(\mathrm{C}-\mathrm{Cl}), 1027,824,681,665$. HRMS (m/z ESI $\left.{ }^{+}\right)$: found: $422.0883\left(\mathrm{M}^{+}+\mathrm{H}\right.$. $\mathrm{C}_{20} \mathrm{H}_{16} \mathrm{~N}_{3} \mathrm{O}_{2} \mathrm{ClF}_{3}$ requires: 422.0883). HPLC: 96.2\% (tR: $\left.32.2 \mathrm{~min}\right)$.

\subsubsection{4'-Sulfonamide-3-[4-chloro-3 trifluoromethylphenylamino]diphenylether (75)}

Compound 40 (100 mg, $0.26 \mathrm{mmol}, 1$ eq.), sulfamoyl chloride (30 mg, $0.26 \mathrm{mmol}, 1$ eq.) and $\mathrm{NEt}_{3}\left(0.05 \mathrm{~mL}, 0.29 \mathrm{mmol}, 1.1\right.$ eq.) were dissolved in $\mathrm{CH}_{2} \mathrm{Cl}_{2}(2 \mathrm{~mL})$ and stirred at overnight at room temperature. The mixture was then washed with water and the organic layer extracted with EtOAc, washed with brine, dried over $\mathrm{MgSO}_{4}$, concentrated under vacuum and purified by silica gel chromatography (hexanes:EtOAc) to get 75 as a light brown solid (95 mg, 80\%). Mp: $124-126{ }^{\circ} \mathrm{C}$. $\delta_{\mathrm{H}}\left(400 \mathrm{MHz}, \mathrm{CD}_{3} \mathrm{OD}\right): 6.54(\mathrm{dd}, J=8.2,2.3 \mathrm{~Hz}, 1 \mathrm{H}, \mathrm{H}-4), 6.69(\mathrm{t}, J=2.2 \mathrm{~Hz}, 1 \mathrm{H}, \mathrm{H}-2), 6.84(\mathrm{dd}, J=8.1$, $2.1 \mathrm{~Hz}, 1 \mathrm{H}, \mathrm{H}-6), 6.99\left(\mathrm{~d}, J=9.0 \mathrm{~Hz}, 2 \mathrm{H}, \mathrm{H}-8\right.$ and $\left.\mathrm{H}-8^{\prime}\right), 7.21-7.26(\mathrm{~m}, 4 \mathrm{H}, \mathrm{H}-9$ and H-9', H-16, H-5), 7.34-7.38 (m, 2H, H-12, H-15). $\delta_{\mathrm{C}}\left(100 \mathrm{MHz}, \mathrm{CD}_{3} \mathrm{OD}\right): 109.1$ (CH Ar, C-2), 112.2 (CH Ar, C-4), 113.8 (CH Ar, C-6), 116.1 (q, J = 5.5 Hz, C-12, CH Ar), 121.1 (2 CH Ar, C-8 and C-8'), 121.2 (CH Ar, C-16), 121.9 (qC, C-14), 123.2 (2 CH Ar, C-9 and C-9'), $124.4\left(\mathrm{~d}, J=272.5 \mathrm{~Hz}, \mathrm{qCF}_{3}\right), 129.7$ (d, J = 30.9 Hz, qC, C-13), 131.5 (CH Ar, C-5), 133.3 (CH Ar, C-15), 136.1 (qC), 144.6 (qC), 145.1 (qC), 154.4 (qC), 160.5 (qC). $\delta_{\mathrm{F}}\left(376 \mathrm{MHz}, \mathrm{CD}_{3} \mathrm{OD}\right):-64.19(\mathrm{~s}) . v_{\max }(\mathrm{ATR}) / \mathrm{cm}^{-1}: 3404(\mathrm{NH}), 3279(\mathrm{NH}), 1596(\mathrm{~S}=\mathrm{O}), 1489$ (S=O), $1143(\mathrm{C}-\mathrm{O}), 1153\left(\mathrm{CF}_{3}\right), 1125(\mathrm{C}-\mathrm{N}), 830(\mathrm{C}-\mathrm{Cl}), 821$. HRMS $\left(\mathrm{m} / \mathrm{z} \mathrm{ESI}^{-}\right)$: found: $456.0397\left(\mathrm{M}^{-}-\mathrm{H}\right.$ $\mathrm{C}_{19} \mathrm{H}_{14} \mathrm{~N}_{3} \mathrm{O}_{3} \mathrm{SClF}_{3}$ requires: 456.0397). HPLC: $99.3 \%$ ( $\left.t \mathrm{R}: 35.4 \mathrm{~min}\right)$.

\subsection{Biochemistry}

\subsubsection{Cell Viability Studies (alamarBlue)}

Cells were counted and seeded in 96-well plates at a density of $2 \times 10^{5}$ cells/mL for HL-60, $2.5 \times 10^{4}$ cells/mL for MCF-7, MCF10A and HeLa, $1 \times 10^{5}$ cells/mL for HCT116 and HKH-2, all of them in their respective media. The 96-well plates were then treated with a 1:100 dilution of stock concentrations of drugs or EtOH (1\% v/v)/DMSO $(0.1 \% v / v)$ as vehicle control in triplicate. Three blank wells containing $200 \mu \mathrm{L}$ RPMI with no cells were also set-up as blanks. After a $72 \mathrm{~h}$ incubation, $20 \mu \mathrm{L}$ of alamarBlue was added to each well. The plates were incubated in darkness at $37{ }^{\circ} \mathrm{C}$ for $4-5 \mathrm{~h}$ using a Molecular Devices microplate reader, the fluorescence (F) was then read at an excitation wavelength of $544 \mathrm{~nm}$ and an emission wavelength of $590 \mathrm{~nm}$. Cell viability was then determined by subtracting the mean blank fluorescence $(\mathrm{Fb})$ from the treated sample fluorescence $(\mathrm{Fs})$ and expressing this as a percentage of the fluorescence of the blanked vehicle control $(\mathrm{Fc})$. This is demonstrated in the equation below. The results were then plotted as a nonlinear regression, sigmoidal dose-response curves on Prism, from which the $\mathrm{IC}_{50}$ value for each drug was determined. 


\subsubsection{Flow Cytometry}

Apoptosis was analysed using annexin V fluorescein isothiocyanate (FITC) and propidium iodide (PI). HL-60 cells were seeded at a density of $2 \times 10^{5}$ cells $/ \mathrm{mL}$ in 12 well plates. Cells were then treated with either vehicle $(0.5 \%$ ethanol), $2(5 \mu \mathrm{M}), 3(5 \mu \mathrm{M})$, or $4(4 \mu \mathrm{M})$ for $48 \mathrm{~h}$. Following treatment, HL60 cells were collected and washed with annexin V binding buffer ( $5 \mathrm{mM}$ HEPES, $70 \mathrm{mM} \mathrm{NaCl}$, $1.25 \mathrm{mM} \mathrm{CaCl} 2 \mathrm{pH}$ 7.4) and stained with annexin V-FITC (iQ Corporation, Groningen, The Netherlands) for $20 \mathrm{~min}$. Following washing with annexin V binding buffer, cells were resuspended in PI $(0.5 \mu \mathrm{g} / \mathrm{mL})$ in binding buffer and analysed on BD FACS Canto II flow cytometer (BD Sciences) using FloJo software (Ashland, OR, USA).

\subsubsection{Western Blotting}

HL60s were seeded in T25 flasks at $50 \times 10^{4}$ cells $/ \mathrm{mL}$ and cells were treated with either vehicle $[0.5 \%$ $\mathrm{EtOH}(v / v)], \mathbf{1}-\mathbf{4}, \mathbf{9}$ or $\mathbf{5 2}(5 \mu \mathrm{M})$, as well as $\mathbf{1}(10 \mu \mathrm{M}$ as reported [9]). After $16 \mathrm{~h}$, cells were collected and washed with PBS. Cell pellets were re-suspended in cold cell lysis buffer (radio-immunoprecipitation assay buffer) supplemented with 1\% phosphatase inhibitor cocktail 2 and 3 (Sigma) and 10\% protease inhibitor (Roche). Cells were lysed for $30 \mathrm{~min}$ on ice. Protein concentration was then determined by BCA assay. Lysates were boiled with Laemmli sample buffer [Tris-HCL $50 \mathrm{mM}$ (pH 6.7), glycerol 10\% $(w / v)$, sodium dodecyl sulphate $2 \%(w / v)$, bromophenol blue $0.02 \%(w / v)$ ] containing DTT $50 \mu \mathrm{M}$ for $10 \mathrm{~min}$ at $90^{\circ} \mathrm{C}$. Moreover, $20 \mu \mathrm{g}$ of lysates were resolved by sodium dodecyl sulphate polyacrylamide gel electrophoresis (SDS-PAGE) and transferred onto PVDF transfer membrane (EMD Millipore). Membranes were blocked with 5\% non-fat milk and probed with primary antibodies for ERK and phospho-ERK (Cell Signalling). Anti-GAPDH was used as a loading control (Calbiochem).

\section{Conclusions}

Taking all of these results into account, the following SARs were drawn in terms of HL-60 cytotoxicity; for example, for a good cytotoxicity bulky substituents $\left(4-\mathrm{Br} / \mathrm{Cl}\right.$ and $\left.3-\mathrm{CF}_{3}\right)$ in the phenyl ring of the hydrophobic moiety are needed; replacement of the di-substituted guanidinium as in compound 1 by a shorter - $\mathrm{NH}$ - link is also beneficial; a mono-substituted guanidinium group at the position $4^{\prime}$ of the phenyloxyaryl core gives good cytotoxic activity; additionally, substituting one of the phenyl rings by a 2-pyridinyl to facilitate IMHB seems also to increase the cytotoxic activity in the $3,4^{\prime}$-bis-guanidinium series. On the negative side, in the bis-guanidinium diphenyl ether series, when only one substituent is kept in the phenyl ring of the hydrophobic moiety (4-Br or 4-F as in 8 or 5) or both are very small (3,4-diF as in 6), cytotoxicity decreases or is completely abolished. This is not the case either in the amino-guanidinium diphenyl ether or in the bis-guanidinium phenyloxypyridine series where mono-substituted or di-fluoro phenyl rings in the hydrophobic moiety still exhibit good HL-60 cytotoxicity (i.e., compounds $28-30$ or 49 and 51).

Future work will be required to investigate the molecular target(s) of our guanidinium derivatives, but nonetheless, while compound 2, 9, and $\mathbf{5 2}$ seem to be improved derivatives of previous lead molecule 1, compounds 3 and 4 can be considered excellent hit molecules in the search for new anticancer therapies.

Supplementary Materials: The following are available online at http://www.mdpi.com/1424-8247/13/12/485/s1, synthetic details (general information, general procedures, characterisation of intermediates); computational details (Figure S1, Figure S2, Figure S3, Figure S4 and Figure S5); theoretical physicochemical and pharmacokinetic parameters (Table S1, Table S2, and Table S3, Figure S6); biochemical protocols (Figure S7, Figure S8, Figure S9, Figure S10, Figure S11, Figure S12, Figure S13); NMR spectra of final salts; and HPLC chromatograms of final salts.

Author Contributions: Conceptualization, V.P., A.M.M., D.M.Z., and I.R.; Formal analysis, V.P., H.B.M., R.A., and I.R.; Funding acquisition, A.M.M., D.M.Z., and I.R.; Investigation, V.P., H.B.M., and R.A.; Methodology, V.P.; Supervision, A.M.M., D.M.Z., and I.R.; Writing-original draft, V.P., and I.R.; Writing—review and editing, V.P., H.B.M., R.A., A.M.M., D.M.Z., and I.R. All authors have read and agreed to the published version of the manuscript. 
Funding: This research was funded by the School of Chemistry at Trinity College Dublin (V.P.), the Irish Research Council (GOIPG/2017/834, H.B.M.), and the John Scott PhD fellowship from the School of Biochemistry \& Immunology and the School of Medicine at Trinity College Dublin (R.A.).

Acknowledgments: Thanks are given to the Irish Centre for High-End Computing (ICHEC) for the provision of computational facilities.

Conflicts of Interest: The authors declare no conflict of interest.

\section{References}

1. Hanahan, D.; Weinberg, R.A. The hallmarks of cancer. Cell 2000, 100, 57-70. [CrossRef]

2. Roberts, P.J.; Der, C.J. Targeting the Raf-MEK-ERK mitogen-activated protein kinase cascade for the treatment of cancer. Oncogene 2007, 26, 3291-3310. [CrossRef] [PubMed]

3. Davies, H.; Bignell, G.R.; Cox, C.; Stephens, P.; Edkins, S.; Clegg, S.; Teague, J.; Woffendin, H.; Garnett, M.J.; Bottomley, W.; et al. Mutations of the BRaf gene in human cancer. Nature 2002, 417, 949-954. [CrossRef] [PubMed]

4. Michaloglou, C.; Vredeveld, L.C.; Mooi, W.J.; Peeper, D.S. BRaf (E600) in benign and malignant human tumours. Oncogene 2008, 27, 877-895. [CrossRef] [PubMed]

5. Wimmer, R.; Baccarini, M. Partner exchange: Protein-protein interactions in the Raf pathway. Trends Biochem. Sci. 2010, 35, 660-668. [CrossRef]

6. Agianian, B.; Gavathiotis, E. Current insights of BRaf inhibitors in cancer. J. Med. Chem. 2018, 61, 5775-5793. [CrossRef]

7. Zhang, J.; Yang, P.L.; Gray, N.S. Targeting cancer with small molecule kinase inhibitors. Nat. Rev. Cancer 2009, 9, 28-39. [CrossRef]

8. Diez-Cecilia, E.; Kelly, B.; Perez, C.; Zisterer, D.M.; Nevin, D.K.; Lloyd, D.G.; Rozas, I. Guanidinium-based derivatives: Searching for new kinase inhibitors. Eur. J. Med. Chem. 2014, 81, 427-441. [CrossRef]

9. Diez-Cecilia, E.; Carson, R.; Kelly, B.; van Schaeybroeck, S.; Murray, J.T.; Rozas, I. Probing a 3,4'-bis-guanidinium diaryl derivative as an allosteric inhibitor of the Ras pathway. Bioorg. Med. Chem. Lett. 2015, 25, 4287-4292. [CrossRef]

10. Trujillo, C.; Previtali, V.; Rozas, I. A theoretical model of the interaction between phosphates in the ATP molecule and guanidinium systems. Theor. Chem. Acc. 2016, 135, 260. [CrossRef]

11. Liau, N.P.D.; Wendorff, T.J.; Quinn, J.G.; Steffek, M.; Phung, W.; Liu, P.; Tang, J.; Irudayanathan, F.J.; Izadi, S.; Shaw, A.S.; et al. Negative regulation of RAF kinase activity by ATP is overcome by 14-3-3-induced dimerization. Nat. Struct. Mol. Biol. 2020, 27, 134-141. [CrossRef]

12. Previtali, V.; Trujillo, C.; Boisson, J.-C.; Khartabil, H.; Hénon, E.; Rozas, I. Development of the first model of a phosphorylated, ATP/Mg2+-containing B-Raf monomer by molecular dynamics simulations: A tool for structure-based design. Phys. Chem. Chem. Phys. 2017, 19, 31177-31185. [CrossRef]

13. Kelly, B.; O’Donovan, D.H.; O’Brien, J.; Blanco, F.; Rozas, I. Pyridin-2-yl Guanidine derivatives: Conformational control induced by intramolecular hydrogen bonding interactions. J. Org. Chem. 2011, 76, 9216-9227. [CrossRef] [PubMed]

14. Dardonville, C.; Goya, P.; Rozas, I.; Alsasua, A.; Martín, M.I.; Borrego, M.J. New aromatic iminoimidazolidine derivatives as alpha1-adrenoceptor antagonists: A novel synthetic approach and pharmacological activity. Bioorg. Med. Chem. 2000, 8, 1567-1577. [CrossRef]

15. Okaniwa, M.; Hirose, M.; Imada, T.; Ohashi, T.; Hayashi, Y.; Miyazaki, T.; Arita, T.; Yabuki, M.; Kakoi, K.; Kato, J.; et al. Design and synthesis of novel DFG-out RAF/vascular endothelial growth factor receptor 2 (VEGFR2) inhibitors. 1. Exploration of [5,6]-fused bicyclic scaffolds. J. Med. Chem. 2012, 55, 3452-3478. [CrossRef] [PubMed]

16. Surrya, D.S.; Buchwald, S.L. Dialkylbiaryl phosphines in Pd-catalyzed amination: A user's guide. Chem. Sci. 2011, 2, 27-50. [CrossRef] [PubMed]

17. Bellamy, F.D.; Ou, K. Selective reduction of aromatic nitro compounds with stannous chloride in non acidic and non aqueous medium. Tetrahedron Lett. 1984, 25, 839-842. [CrossRef]

18. Ishimoto, K.; Fukuda, N.; Nagata, T.; Sawai, Y.; Ikemoto, T. Development of a scalable synthesis of a vascular endothelial growth factor receptor-2 kinase inhibitor: Efficient construction of a 6-Etherified [1,2,4]Triazolo[1,5-a]pyridine-2-amine core. Org. Process Res. Dev. 2014, 18, 122. [CrossRef] 
19. Oguro, Y.; Cary, D.R.; Miyamoto, N.; Tawada, M.; Iwata, H.; Miki, H.; Hori, A.; Imamura, S. Design, synthesis, and evaluation of novel VEGFR2 kinase inhibitors: Discovery of [1,2,4]triazolo[1,5-a]pyridine derivatives with slow dissociation kinetics. Biorg. Med. Chem. 2013, 21, 4714-4729. [CrossRef]

20. Previtali, V.; Trujillo, C.; Amet, R.; Zisterer, D.M.; Rozas, I. Effect of isouronium/ guanidinium substitution on the efficacy of a series of novel anti-cancer agents. Med. Chem. Comm. 2018, 9, 735-743. [CrossRef]

21. Appel, R.; Berger, G. Hydrazinsulfonsäure-amide, I. Über das Hydrazodisulfamid. Eur. J. Inorg. Chem. 1958, 91, 1339-1341. [CrossRef]

22. Shahani, V.M.; Ball, D.P.; Ramos, A.V.; Li, Z.H.; Spagnuolo, P.A.; Haftchenary, S.; Schimmer, A.D.; Trudel, S.; Gunning, P.T. A 2,6,9-hetero-trisubstituted purine inhibitor exhibits potent biological effects against multiple myeloma cells. Bioorg. Med. Chem. 2013, 21, 5618-5628. [CrossRef] [PubMed]

23. Daina, A.; Michielin, O.; Zoete, V. SwissADME: A free web tool to evaluate pharmacokinetics, drug-likeness and medicinal chemistry friendliness of small molecules. Sci. Rep. 2017, 7, 42717. [CrossRef] [PubMed]

24. Marvin was used for calculating basicity $(\mathrm{pKaH})$ of chemical structures, Marvin 17.21.0, ChemAxon. Available online: https://www.chemaxon.com (accessed on 28 June 2019).

25. Wu, P.; Nielsen, T.E.; Clausen, M.H. Small-molecule kinase inhibitors: An analysis of FDA-approved drugs. Drug Discov. Today 2016, 21, 5-10. [CrossRef] [PubMed]

26. Ertl, P.; Rohde, B.; Selzer, P. Fast calculation of molecular polar surface area as a sum of fragment-based contributions and its application to the prediction of drug transport properties. J. Med. Chem. 2000, 43, 3714-3717. [CrossRef] [PubMed]

27. Davis, A.; Ward, S.E. The Handbook of Medicinal Chemistry: Principles and Practice; Royal Society of Chemistry: London, UK, 2014.

28. Daina, A.; Zoete, V. A Boiled-Egg to predict gastrointestinal absorption and brain penetration of small molecules. Chem. Med. Chem. 2016, 11, 1117-1121. [CrossRef] [PubMed]

29. Montanari, F; Ecker, G.F. Prediction of drug-ABC-transporter interaction-Recent advances and future challenges. Adv. Drug Deliv. Rev. 2015, 86, 17-26. [CrossRef]

30. Wilhelm, S.M.; Adnane, L.; Newell, P.; Villanueva, A.; Llovet, J.M.; Lynch, M. Preclinical overview of sorafenib, a multikinase inhibitor that targets both Raf and VEGF and PDGF receptor tyrosine kinase signaling. Mol. Cancer Ther. 2008, 7, 3129-3140. [CrossRef]

31. Keating, G.M.; Santoro, A. Sorafenib: A review of its use in advanced hepatocellular carcinoma. Drugs 2009, 69, 223-240. [CrossRef]

32. Barrett, S.D.; Bridges, A.J.; Dudley, D.T.; Saltiel, A.R.; Fergus, J.H.; Flamme, C.M.; Delaney, A.M.; Kaufman, M.; LePage, S.; Leopold, W.R. The discovery of the benzhydroxamate MEK inhibitors CI-1040 and PD 0325901. Bioorg. Med. Chem. Lett. 2008, 18, 6501-6504. [CrossRef]

33. Gulhati, P.; Zaytseva, Y.Y.; Valentino, J.D.; Stevens, P.D.; Kim, J.T.; Sasazuki, T.; Shirasawa, S.; Lee, E.Y.; Weiss, H.L.; Dong, J.; et al. Sorafenib enhances the therapeutic efficacy of rapamycin in colorectal cancers harboring oncogenic KRAS and PIK3CA. Carcinogenesis 2012, 33, 1782-1790. [CrossRef] [PubMed]

34. Karoulia, Z.; Wu, Y.; Ahmed, T.; Xin, Q.; Bollard, J.; Krepler, C.; Wu, X.; Zhang, C.; Bollag, G.; Herlyn, M.; et al. An integrated model of RAF inhibitor action predicts inhibitor activity against oncogenic BRAF signaling. Cancer Cell. 2016, 30, 485-498. [CrossRef] [PubMed]

35. Frisch, M.J.; Trucks, G.W.; Schlegel, H.B.; Scuseria, G.E.; Robb, M.A.; Cheeseman, J.R.; Scalmani, G.; Barone, V.; Petersson, G.A.; Nakatsuji, H.; et al. Gaussian 16, Revision C.01; Gaussian, Inc.: Wallingford, CT, USA, 2016.

36. Trott, O.; Olson, A.J. AutoDock Vina: Improving the speed and accuracy of docking with a new scoring function, efficient optimization and multithreading. J. Comput. Chem. 2010, 31, 455-461. [CrossRef] [PubMed]

37. Humphrey, W.; Dalke, A.; Schulten, K. VMD-visual molecular dynamics. J. Mol. Graph. 1996, 14, 33-38. [CrossRef]

Publisher's Note: MDPI stays neutral with regard to jurisdictional claims in published maps and institutional affiliations. 